\title{
Molecular Mechanisms of Inner Ear Development
}

\section{Doris K. Wu and Matthew W. Kelley}

National Institute on Deafness and Other Communication Disorders, Rockville, Maryland 20850

Correspondence:wud@nidcd.nih.gov

\section{SUMMARY}

The inner ear is a structurally complex vertebrate organ built to encode sound, motion, and orientation in space. Given its complexity, it is not surprising that inner ear dysfunction is a relatively common consequence of human genetic mutation. Studies in model organisms suggest that many genes currently known to be associated with human hearing impairment are active during embryogenesis. Hence, the study of inner ear development provides a rich context for understanding the functions of genes implicated in hearing loss. This chapter focuses on molecular mechanisms of inner ear development derived from studies of model organisms.

\section{Outline}

1 Introduction

2 Axial specification

3 Specification of neural and sensory fates

4 Formation of semicircular canals and cristae
5 Formation of the cochlear duct

6 Future directions

References

Editors: Patrick P.L. Tam, W. James Nelson, and Janet Rossant

Additional Perspectives on Mammalian Development available at www.cshperspectives.org

Copyright (C 2012 Cold Spring Harbor Laboratory Press; all rights reserved; doi: 10.1101/cshperspect.a008409

Cite this article as Cold Spring Harb Perspect Biol 2012;4:a008409 


\section{INTRODUCTION}

The inner ear originates from a thickening of the surface ectoderm next to the hindbrain known as the otic placode. This thickened epithelium quickly deepens to form a cup and then closes to form a vesicle. Over time the otocyst undergoes a series of morphogenetic events to give rise to the mature inner ear structure, which can be roughly divided into a dorsal vestibular and ventral auditory component in amniotes (Fig. 1) (Morsli et al. 1998). The vestibule consists of three orthogonally arranged semicircular canals and their associated sensory structures, the ampullae, housing the sensory tissue, referred to as cristae. Together this apparatus detects angular head movements. Linear acceleration is detected by the two otolithic organs, the maculae of the utricle and saccule, both of which are overlain by mineralized structures (otoconia) that serve as mass loads in the detection of gravity. Sound is perceived by the auditory component of the inner ear, which varies structurally by vertebrate phylum. In all mammals except monotremes, it exists as a coiled cochlear duct that extends between one and three-quarters to three and three-quarters turns depending on the species. Within the duct the sensory epithelium, known as the organ of Corti, forms a thin stripe that winds along its entire length. In birds the auditory component is a slightly curved tube named the basilar papilla.

By the otocyst stage, three primary cell fates-neural, sensory, and nonsensory-are presumed to have been established (Fig. 2). Cells fated to develop as neurons delaminate from the anteroventral region of the otic epithelium, migrate short distances, and then coalesce as neurons of the cochleovestibular ganglion (CVG). Cells fated to give rise to sensory patches, referred to as prosensory cells, develop as sensory hair cells and supporting cells. Finally, cells with nonsensory fates develop into structures with architectural, secretory, and/or absorptive functions, such as the endolymphatic duct and semicircular canals.

Induction of the otic placode is dependent on a number of events, beginning with the formation of a specialized region surrounding the neural plate known as the preplacodal region, which gives rise to all cranial placodes (Bailey and Streit 2006; Schlosser 2006). A number of factors such as fibroblast growth factors (FGFs) and antagonists of Wnts and bone morphogenetic proteins (BMPs) are known to be involved in establishing the preplacodal region, but the mechanisms that induce specific placodes within this region are not clear (Bailey and Streit 2006; Schlosser 2006). At the preotic axial level, the region divides to form the otic and epibranchial placodes (Freter et al. 2008). Studies from the mouse, chicken, and zebrafish all indicate that otic placode induction is dependent on Wnts and FGFs provided by the surrounding tissues, even though the specific Wnts and FGFs, as well as their tissues of origin, are not consistently conserved among the three species (Ladher et al. 2000; Wright and Mansour 2003; Phillips et al. 2004; Wright et al. 2004; Ohyama et al. 2006; Freter et al. 2008).

After otic placode induction, the otic epithelium continues to be influenced by signaling information from its surrounding tissues in acquiring its positional identity along the anterior-posterior (AP), the dorsal-ventral (DV), and the medial-lateral (ML) axes. This dependency might extend beyond otocyst formation, because otocysts explanted to ectopic locations in vivo or in vitro do not develop into ears with reasonable morphology unless some periotic mesenchymal tissues, from which signals are emanated, are included in the transplant ( $\mathrm{Li}$ et al. 1978; Corwin and Cotanche 1989; Swanson et al. 1990). This chapter summarizes what is currently known about the tissues and molecules that instruct inner ear formation

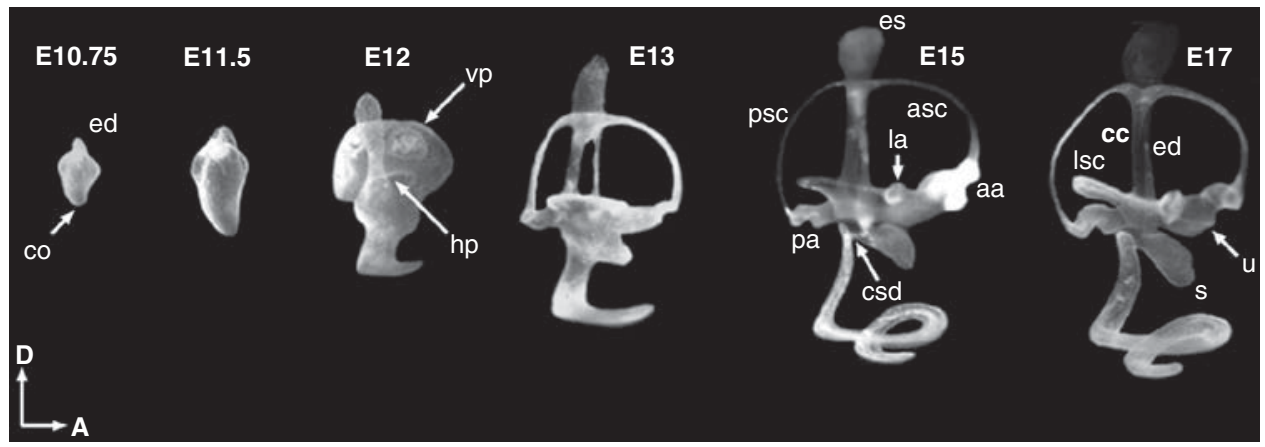

Figure 1. Morphogenesis of the mouse inner ear. Lateral views of paint-filled, right inner ears from E10.75 to E17 (E, embryonic age). Abbreviations: aa, anterior ampulla; asc, anterior semicircular canals; cc, common crus; co, cochlear duct; csd, cochlear saccular duct; ed, endolymphatic duct; es, endolymphatic sac; hp, horizontal canal pouch; la, lateral ampulla; lsc, lateral semicircular canal; pa, posterior ampulla; psc, posterior semicircular canal; s, saccule; u, utricle; vp, vertical canal pouch. Orientations: A, anterior; D, dorsal. (Adapted from Morsli et al. 1998.) 
A
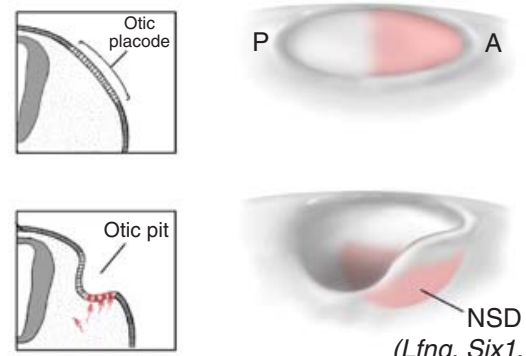

(Lfng, Six1, Eya1,

Sox2, Ngn1*, Delta*)
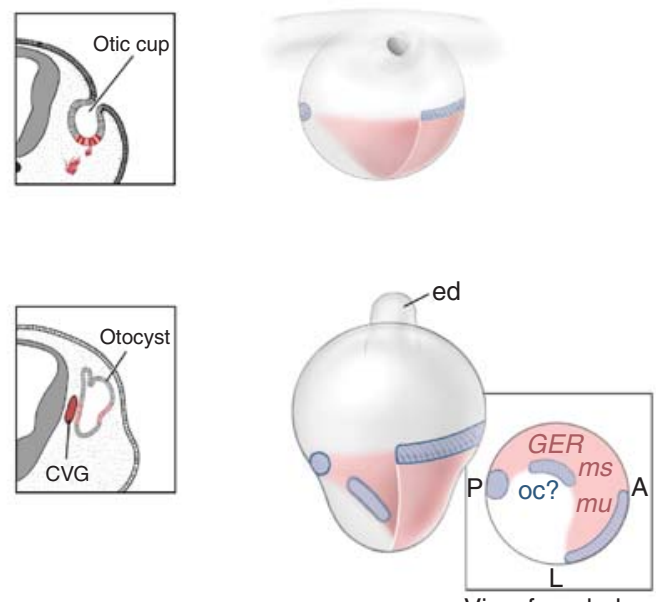

View from below
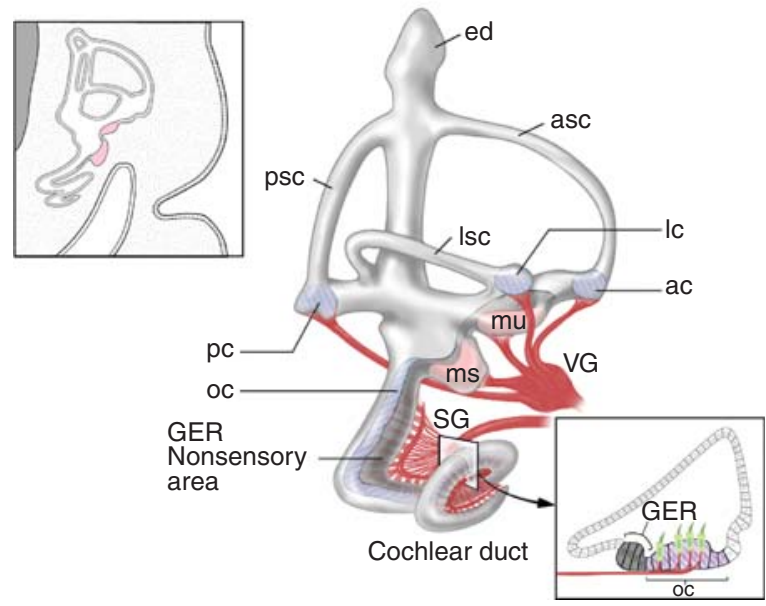

Figure 2. Development of the neural-sensory domain. (A) Proposed derivatives of the NSD based on gene expression patterns and fate-mapping studies. The NSD originated in the anterior region of the invaginating otic placodes, where neuroblasts delaminate to form neurons of the CVG (red). This region also gives rise to macula of the utricle and saccule, as well as nonsensory regions (gray) between sensory patches and the GER of the cochlea. Three separate domains ( pink with blue stripes) that form at the fringe or within a subdivision of the NSD at the otocyst stage give rise to the three cristae and organ of Corti. (B) Neural-competent cells expressing Ngn1 and Delta within the neuralsensory domain delaminate from the otic epithelium to form neuroblasts (red). Delta1 inhibits neighboring cells from developing into neuroblasts via lateral inhibition. The remaining sensory epithelium, including cells that once express Ngn1, develops into sensory hair cells (green), supporting cells (pink), and some nonsensory cells (gray). Asterisks represent genes expressed in a subpopulation of cells within the NSD. Abbreviations: ac, anterior crista; asc, anterior semicircular canal; CVG, cochleovestibular ganglion; ed, endolymphatic duct; es, endolymphatic sac; GER, greater epithelial ridge; lc, lateral crista; lsc, lateral semicircular canal; ms, macula of the saccule; mu, macula of the utricle; NSD, neural-sensory-competent domain; oc, organ of Corti; pc, posterior crista; psc, posterior semicircular canal; SG, spiral ganglion; VG, vestibular ganglion. 
in amniotes, and illustrates how axial information drives cell-fate specification and formation of specific inner ear structures.

\section{AXIAL SPECIFICATION}

The axial identity of the inner ear is specified by signals arising from surrounding tissues, including the neurectoderm, mesoderm, endoderm, and neural crest. A particular axis is specified when positional identity of ear tissues becomes insensitive to changes in extrinsic signals. The timing of this event in amniotes can be revealed using a surgical transplantation approach in chickens, whereby the consequences of inverting one specific axis of the ear rudiment relative to the axes of the host body were assessed following the replacement of an ear rudiment with a contralateral counterpart. The main conclusion from these experiments is that axial specification of the inner ear is a progressive event. The first axis to be specified appears to be the AP axis, at least in terms of the sensory tissues, which occurs well in advance of the DV axis (Wu et al. 1998), but axes for the nonsensory tissues are specified later and independently of the sensory tissues. These multiple steps of axial specification imply a gradual restriction of cell fates over time. Therefore, identifying the timing of axial specification of the inner ear tissue will inform us of when extrinsic signals must be present, and may provide insights into the molecular cascades that accompany the formation of this complex organ.

\subsection{Anterior-Posterior Axis}

The first clear indication of AP asymmetry of the chicken and mouse ear rudiment is the regionalized expression of genes, such as Lunatic fringe (Lfng), Fgf10, Six1, and Sox2, strongly in the anterior but more weakly and diffusely in the posterior region of the otic cup (Fig. 2) (Morsli et al. 1998; Cole et al. 2000; Zheng et al. 2003; Alsina et al. 2004; Kiernan et al. 2005). The anterior region is the neural-sensory-competent domain (NSD) (Fekete and $\mathrm{Wu}$ 2002). The most anterior part of the NSD contains Neurogenin1-positive (Ngn1) cells that are fated to leave the otic epithelium as neural precursors and form the CVG. The posterior otic region gives rise to mostly nonsensory tissues and only one sensory organ: the posterior crista.

Recent studies in both chicken and mouse suggest that retinoic acid (RA), a critical morphogen for early embryogenesis, is required for conferring anterior and posterior identities to the inner ear (Bok et al. 2011). The expression of an RA reporter, RARE-lacZ (retinoic acid response element driving lac $Z$ ), highlights different RA responsiveness between anterior and posterior halves of the otic cup (Fig. $3 \mathrm{~A})$. Moreover, this wave of RA responsiveness regresses caudally away from anterior regions when the otic cup closes. This shift in RA responsiveness is attributed, in part, to caudally shifting expression domains of the RA synthetic and degradation enzymes, Raldh2 (retinaldehyde dehydrogenase 2) and Cyp26 (cytochrome P450-associated RA catabolizing enzyme), respectively (Fig. 3B) (Reijntjes et al. 2004; Sirbu et al. 2005). Gain- and loss-offunction studies in both chicken and mouse collectively indicate that cells in the anterior otic region that are exposed only briefly to RA give rise to neurons and most sensory organs of the inner ear, whereas prolonged exposure and/or higher levels of RA in the posterior otocyst promote formation of nonsensory structures (Bok et al. 2011). Consistent with this inference, local application of RA on the anterior side of the developing otic cup in chicken resulted in an inner ear with two mirror-image posterior domains. Furthermore, one of the key effectors of high RA signaling in the otic epithelium may be the T-box transcription factor Tbx1 (Bok et al. 2011), which was shown to function as a negative regulator of otic neurogenesis (the anterior tissue fate) along the AP axis (Raft et al. 2004). These findings lend support to a compartment-boundary model of cell-fate specification for the inner ear (Fekete 1996).

The RA synthesizing and degradation enzymes responsible for the differential RA response of the ear rudiment are likely to be Cyp26C1, which is expressed in ectoderm anterior to the ear rudiment, and Raldh2, which is expressed in the somites posterior to the otocyst (Fig. 3B) (Reijntjes et al. 2004). Although other RA degradation enzymes are also expressed in rhombomeres adjacent to the ear rudiment, hindbrain rotation experiments rule out their role in AP patterning of the chicken inner ear (Bok et al. 2005). In mice the otic cup also responds differentially to RA along its AP axis (Fig. 3A), although no RA degradation enzyme has yet been identified in the ectoderm adjacent to the ear primordium (MacLean et al. 2001; Tahayato et al. 2003). Therefore, although the requirement of RA in AP patterning seems to be conserved between mice and chicken, the tissues that elicit the differential RA response of the otic epithelium may be different. A gradient of RA signaling has also been implicated in patterning the hindbrain rhombomeres in mice (Sirbu et al. 2005). Thus, it is likely that dynamic RA signaling coordinates the AP patterning of multiple structures in this part of the embryo (Fig. 3B). In zebrafish RA has been shown to restrict the extent of the anterior neurogenic domain through the suppression of neurogenic genes by $t b x 1$ and her9, a zebrafish ortholog of Hes1 (Radosevic et al. 2011). Whether cells within the inner ears of zebrafish are responding differentially to RA along the AP axis is not clear. 
A
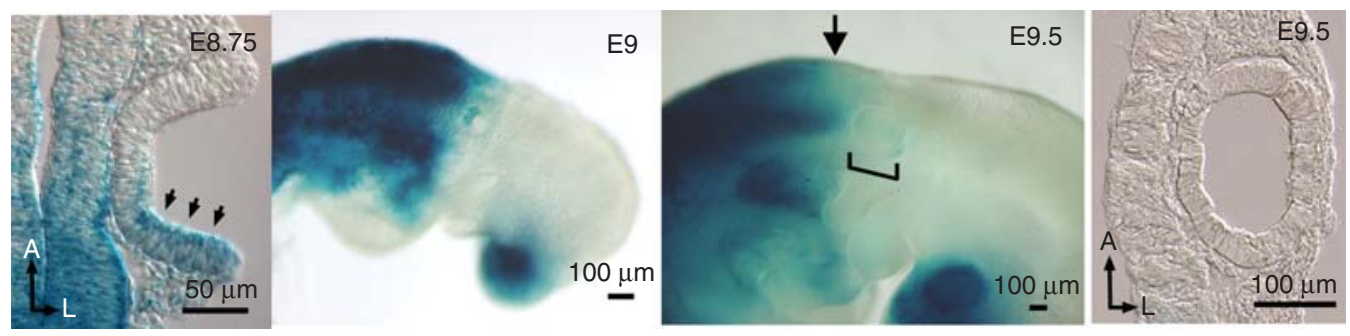

B

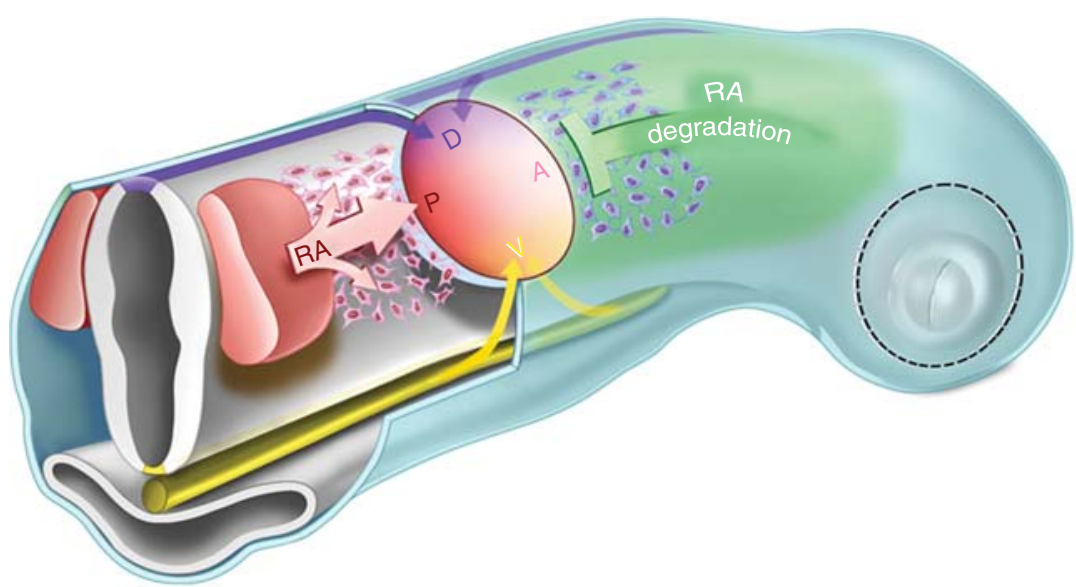

Figure 3. Anterior-posterior axial specification. (A) X-Gal histochemical staining in RARE-lacZ mouse embryos shows a transient gradient of RA responsiveness in the developing inner ear. At the otic cup stage (E8.75), the anterior border of the RA responsiveness is in the middle of the otic cup, and this border shifts caudally by the time the otocyst is formed at E9.5. (B) Model of RA signaling in AP patterning of the chicken inner ear. Somites expressing high levels of the RA synthetic enzyme Raldh2 act as the main source of RA for patterning the inner ear. The RA degradation enzyme Cyp26C1, expressed in the ectoderm rostral to the ear rudiment, modulates the level of RA signaling perceived by the otic epithelium. Secreted molecules from the hindbrain such as Wnts (purple) and Shh (yellow) provide DV axial information to the inner ear.

Besides RA, FGF8, which is expressed in the ectoderm anterior to the ear primordium in chicken, has also been implicated in the establishment of the neurogenic (anterior) fate via up-regulation of Sox3 (Abello et al. 2010). On the other hand, knocking down BMP signaling also suggests a role for BMPs in mediating the nonneurogenic (posterior) fate (Abello et al. 2010). Because FGF and RA are shown in other systems to act antagonistically (Diez del Corral and Storey 2004; Marklund et al. 2004), FGF8 may diminish the responsiveness of the anterior otic region to RA.

\subsection{Dorsal-Ventral Patterning}

In contrast to AP patterning, DV specification is dependent on ectoderm-derived signals from the hindbrain in both chicken and mice (Giraldez 1998; Bok et al. 2005; Riccomagno et al. 2005). DV inversion of a segment of the hindbrain adjacent to the ear rudiment in chicken is sufficient to override potential DV signaling from other tissues and activate ventral genes in dorsal otic tissues (Bok et al. 2005). To date, Wnts secreted from the dorsal hindbrain and Sonic hedgehog (Shh) secreted from the ventral floor plate and notochord have been implicated in patterning of the inner ear DV axis (Fig. 3B). However, the weight of evidence suggests that other unidentified signals originating from the hindbrain are involved as well (Riccomagno et al. 2005; Bok et al. 2007b). For example, BMPs are likely to act as dorsal signaling molecules for the inner ear, although direct experimental proof of this is lacking at present.

The Shh signaling pathway has been well studied (Ribes and Briscoe 2009; Murdoch and Copp 2010) and plays an important role in ventral identities. One of its major actions in target cells is believed to be regulation of the transcription factor Gli3. In the absence of Shh, the Gli3 protein is cleaved and its amino-terminal portion functions as a transcription repressor. However, in the presence of Shh, Shh binds to its receptor Patched, which removes an inhibitory effect on the transmembrane protein Smoothened. As a result, a number of intracellular signaling cascades are initiated that maintain full-length Gli3 protein, which then functions as a transcription activator. Based on several mutant mouse analyses and ablation studies in chicken, it 
was proposed that Shh secreted from the ventral midline generates opposing gradients of Gli3 repressor and Gli2 and Gli3 activators in the otic epithelium, which pattern various inner ear structures along the DVaxis (Fig. 4) (Boket al. 2007c). The most apical region of the cochlear duct requires the highest level of Shh to induce Gli2 and Gli3 activators. The utricle, saccule, and proximal region of the cochlear duct require relatively lower levels of Shh to alleviate the Gli3 repressor function. In contrast, dorsal structures such as the semicircular canals require little Shh and instead are dependent on Gli3 repressor activity for proper formation (Bok et al. 2007b; Brown and Epstein 2011). The upstream activator of Gli3 transcription is not known. In the neural tube, where similar Gli3 repressor and Gli activator gradients are believed to pattern the DV axis of the neural tube,

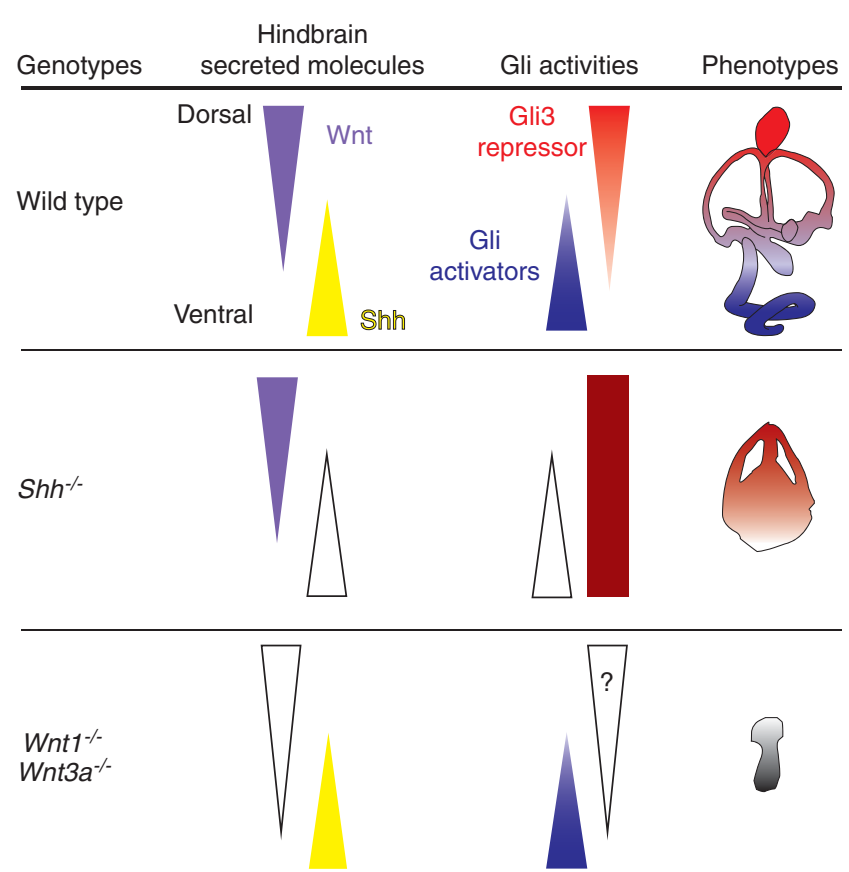

Figure 4. Dorsal-ventral axial specification. The hindbrain is the source of DV axial signaling for the inner ear. In the wild-type embryo, the developing inner ear receives Wnt signaling from the dorsal hindbrain (purple triangle) and Sonic hedgehog (Shh) from the ventral midline structures of the floor plate and notochord. The graded Shh signaling (yellow triangle) results in various levels of Gli activator (blue triangle) and repressor (red triangle) activities in the developing inner ear. The distal region of the cochlear duct (blue region) requires a high level of Gli activators. The proximal region of the cochlear duct and the saccule ( pale red and blue region) require relatively lower levels of Shh signaling for counteracting the Gli3 repressor function. The dorsal vestibular region of the inner ear (red region) requires Gli3 repressor function. In $S h h^{-/-}$ears only the dorsal vestibular region develops. In Wnt1/Wnt3a double mutants, the inner ear is rudimentary and cystic. However, Shh signaling appears normal based on the expression of putative Shh target genes such as Pax2 and Otx2. Whether Gli3 repressor activities are still present in the inner ear of the compound mutant is not clear. there is evidence that transcription of Gli3 is activated by Wnts (Alvarez-Medina et al. 2008). Whether Gli3 is induced by Wnts in the inner ear remains to be explored.

Wnts from the dorsal neural tube have been implicated in otic DV patterning in addition to their earlier role in specifying the otic placode fate (Ohyama et al. 2006; Jayasena et al. 2008). After otic placode specification, there is a continual requirement for Wnts in the DV patterning of the inner ear, based on studies using lithium chloride treatments in otic-hindbrain explant cultures (Riccomagno et al. 2005). Lithium chloride, a Wnt/ $\beta$-catenin pathway agonist, is able to restore, in part, otocyst gene expression patterns altered by ablation of the dorsal neural tube in otic-hindbrain explants.

$W n t 1$ and $W n t 3 a$ are expressed in the dorsal neural tube but not in the otic placode or otocyst. Ears from Wnt1/ Wnt3a double-knockout mice are rudimentary and cystic in structure, indicating that the affected areas are not limited to the dorsal region (Fig. 4) (Riccomagno et al. 2005). These severe phenotypes may be caused by an earlier requirement of Wnts in placode specification, even though Wnt1 or Wnt3a expression is low in the hindbrain during the time of otic placode induction (Parr et al. 1993). Nevertheless, results from genetic fate mapping of cells responding to Wnt signaling in the mouse otocyst using Topgal transgenic mice clearly indicate that the dorsal region of the otic cup and otocyst are responsive to Wnt signaling (Fig. 5A, a,b). It is also possible to track the fates of Wnt-responsive otocyst cells over time by crossing RosalacZ, a Cre reporter strain, with the TopCreERT2 strain. Administration of tamoxifen at specific time points causes Wnt-responsive cells harboring both alleles to permanently express lacZ. Administering tamoxifen between embryonic day (E) 8.5 and 8.75 followed by examination at E9.5 indicates that X-Gal-positive cells span most of the medial wall of the otocyst (Fig. 5A, d) (Riccomagno et al. 2005), covering a much broader area than would be predicted by the TopCreERT2 mRNA or Topgal expression domains (Fig. $5 \mathrm{~A}, \mathrm{a}-\mathrm{c})$. This broader X-Gal-positive domain in TopCreER/Rosa-lacZ inner ears suggests that cells that received Wnt signaling in the dorsal otic region at an earlier age have become displaced or have migrated ventrally by the otocyst stage (Fig. 5A, d, arrows). Thus, the genetic fate-mapping results are consistent with the inner ear phenotypes of Wnt1/Wnt3a double mutants, which involve more than the dorsal region.

In the zebrafish inner ear, hedgehog signaling has been implicated in AP rather than DV patterning (Hammond et al. 2003). Loss of hedgehog signaling resulted in inner ears with a mirror-image duplication of two anterior halves, whereas gain of hedgehog signaling resulted in double posterior ears. More recent results show that in addition 
A

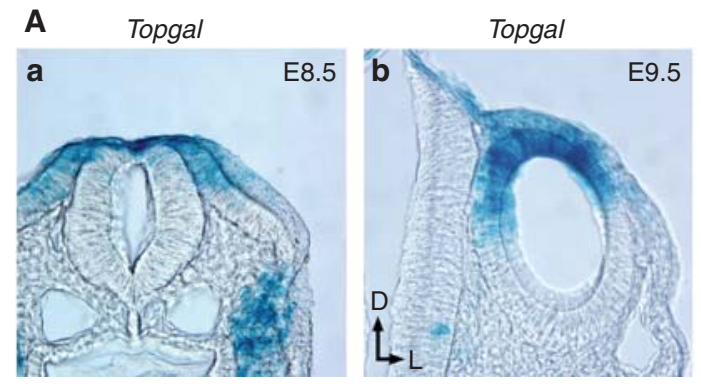

B

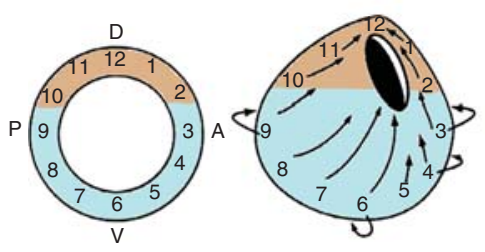

Stage 13.5

(lateral view)

\section{Stage 16.5}

(lateral view)

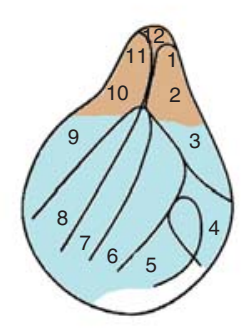

Stage 17

(lateral view)

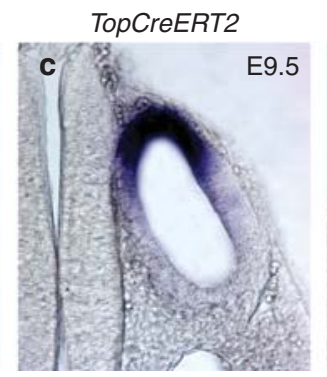

TopCreERT2; Rosa-lacZ

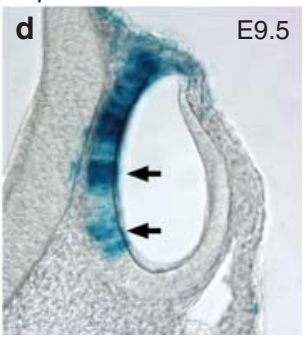

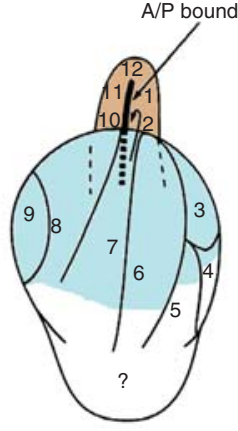

Stage 22

(lateral view)

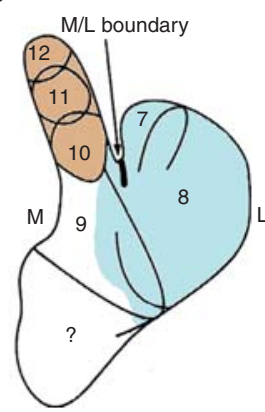

Stage 22

(posterior view)

Figure 5. Fate-mapping studies of the mouse and chicken inner ear. (A) Genetic fate mapping of the Wnt-responsive cells in the mouse otic cup. X-Gal histochemical staining of a Wnt reporter strain, Topgal, shows that Wnt-responsive cells are restricted to the dorsal otic placode $(a)$ and otocyst $(b)$. However, tracing the progeny of the Wnt-responsive cells in TopCreERT2/Rosa-lacZ embryos after administration of tamoxifen at E8.75 shows these cells expanded ventrally ( $d$, arrows) beyond the initial TopCreERT2 mRNA domain $(c)$. (B) Fate mapping of the rim of the chicken otic cup. Injection of lipophilic dyes to the indicated numerical positions at the rim of the otic cup shows that a majority of the cells that constitute the lateral wall of the otocyst (light blue) originated from the ventral posterior region of the otic cup at positions 6,7 , and 8 . The most dorsal region of the otocyst, constituted by cells in positions $1,2,10,11$, and 12 , displaces medially to form the endolymphatic duct ( $\tan )$. The lateral region of the otocyst gives rise to the vertical and horizontal canal pouches. ( $A$ adapted from Riccomagno et al. 2005; $B$ adapted from Brigande et al. 2000; Fig. 5 reprinted, with permission, (C) Elsevier.)

to the double posterior phenotypes, too much hedgehog signaling also affects DV and ML patterning, thus narrowing the differences between fish and amniotes (Hammond et al. 2010). For example, there is an increased prevalence of a missing posterior canal phenotype in $S h h^{-1-}$ ears (Brown and Epstein 2011), suggesting that the posterior canal is more sensitive to a lack of Shh signaling than the anterior canal. Consistently, in mutants that presumably have too much Shh signaling such as Extra-toes, in which Gli3 encodes a functional null protein, the anterior canal is truncated (Bok et al. 2007c). Therefore, these canal phenotypes in mice resemble those in the zebrafish, in that too much or too little hedgehog signaling affects anterior and posterior otic patterning, respectively.

\subsection{Medial-Lateral Axis}

Far less is known about how the ML axis of the ear is specified. Hindbrain signaling is involved, and this signaling is believed to be mediated, at least in part, through Gbx2 expressed in the otic epithelium (Lin et al. 2005; Choo et al. 2006). Also, it has been suggested that the medial otic region may be the first to be specified, followed by AP, DV, and the lateral axis (Bok et al. 2007b). This notion is largely based on early initiation of genes such as Pax2 and Gbx2 at the otic placode stage, which subsequently are associated with the medial half of the developing otocyst. However, there is no direct experimental evidence that pinpoints the timing of medial or lateral axial specification. Rotating the ML axis of an otocyst resulted in malformed ears with mixed expression patterns of medial and lateral genes that were difficult to interpret (Wu et al. 1998). This is partially attributed to the technical difficulty in generating a precise ML inversion owing to the geometry of the newly formed otocyst, which is more like the shape of a covered bowl (flat on the lateral surface) than a perfect sphere (Fig. $5 \mathrm{~A}$ ).

Further information about the origin of the cells in the lateral otic region comes from a fate-mapping study using 
lipophilic dyes to follow the fate of cells at the rim of the chicken otic cup (Brigande et al. 2000). This study shows that as the otic cup closes to form a cyst, the lateral wall of the otocyst is primarily composed of cells that originated from the ventral posterior rim of the otic cup at the 6,7, and 8 o'clock positions (Fig. 5B). After otic cup closure, the most dorsal region of the otocyst is displaced medially to form the endolymphatic duct (Fig. 5B, tan), whereas the lateral wall mainly gives rise to the vertical and horizontal pouches that form the three semicircular canals (Fig. 5B, light blue). Thus, it is conceivable that inner ears with an early failure in dorsal or medial specification may have additional malformations beyond the primary defective region.

Early ML specification of the inner ear may also be involved in the specification of vestibular and auditory neuronal fates. After neuroblasts delaminate from the NSD of the otic cup and otocyst, they coalesce to form the CVG, which subsequently splits to form the dorsal vestibular and ventral auditory ganglia (spiral ganglion in mammals). It is not clear when vestibular and auditory neuronal fates are specified, and several lines of evidence suggest that this specification may be an early event before neuroblasts leave the otic epithelium. Fate-mapping results from both chicken and mouse suggest that vestibular neuroblasts are first to delaminate from the lateral region of the NSD, whereas auditory neuroblasts delaminate slightly later from the medial region (Koundakjian et al. 2007; Bell et al. 2008). The two neurogenic regions within the otic epithelium where neuroblasts exit are also molecularly distinct from each other; the vestibular region is Fgf3-positive, whereas the auditory region is Gata3- and Lmxla-positive (Lawoko-Kerali et al. 2004; Koo et al. 2009). Furthermore, in the absence of $L m x l a$, the vestibular neurogenic marker $\mathrm{Fgf3}$ is expanded medially, and there is an increase in the production of vestibular neurons as a result (Koo et al. 2009). Therefore, the vestibular and auditory neuroblasts may acquire their fates based on their position of origin within the developing ML axis of the inner ear.

\section{SPECIFICATION OF NEURAL AND SENSORY FATES}

\subsection{Extrinsic Signals Regulating the Neural-Sensory Domain}

Specification of the three primary axes dictates the formation of all inner ear structures. In terms of the NSD, RA signaling imparts AP differences and establishes the NSD in the anterior otic region. Whereas ML axial signaling may determine the type of neurons generated in the NSD, one of the roles of DV signaling is likely to restrict the NSD domain to the ventral otic region, an effect that is mediated in part by a balance of Wnts and Shh signaling (Figs. 2-4) (Riccomagno et al. 2005; Ohyama et al. 2006; Freyer and Morrow 2010; Brown and Epstein 2011).

\subsection{Specification of Cell Fates}

At the otic cup stage, the NSD is loosely defined by a number of overlapping gene expression domains such as $L f n g$, Sox2, Eya1, and Sixl (Fig. 2). Whereas deletion of Lfng has no obvious effect in the inner ear (Zhang et al. 2000), Sox2-, Eya1-, and Six1-null inner ears all have both neural and sensory defects (Xu et al. 1999; Zheng et al. 2003; Ozaki et al. 2004; Kiernan et al. 2005; Zou et al. 2008). Finally, deletion of the Notch ligand Jagged 1 or the Notch effector Rbpj leads to significant sensory defects, although similar or reciprocal effects on neuronal development have not been confirmed (Brooker et al. 2006; Basch et al. 2011; Yamamoto et al. 2011).

Ngn1, which encodes a basic helix-loop-helix region (bHLH) transcription factor, is one of the first molecular markers associated with the neurogenic fate in the inner ear (Ma et al. 1998, 2000). Ngn1 expression is followed by the initiation of NeuroD, which also encodes a bHLH transcription factor, and the neurogenic cells soon delaminate from the otic epithelium to form the neurons of the CVG. These neural-fated cells also express Delta1, a ligand of the Notch signaling pathway, which is postulated to function by inhibiting the neighboring cells from developing into neuroblasts (Adam et al. 1998; Brooker et al. 2006). The remaining cells within the sensory epithelium are believed to gradually segregate over time to form various sensory organs consisting of sensory hair cells and supporting cells (Fig. 2).

\subsection{Relationships between the Neural and Sensory Domains}

Fate-mapping studies using replication-incompetent retroviruses in chicken provided evidence for a common lineage between neurons in the CVG and sensory cells in the utricle (Satoh and Fekete 2005). More recent genetic fate mapping of the Ngn1-expressing cells in mice indicate that sensory organs of both the utricle and saccule share a lineage relationship with neurons of the CVG (Fig. 2) (Raft et al. 2007). In addition, some nonsensory regions between the two sensory organs and cells in the greater epithelial ridge of the cochlear duct also share the same lineage. Based on the various cell types that are derived from the Ngn1-positive lineage, $N g n 1$ fits the criteria of functioning as a proneural gene in the inner ear, expressed broadly in a proneural domain initially and then subsequently restricted to a subset of neural precursor cells (Raft et al. 2007). Moreover, 
enforced expression of $\mathrm{Ngn} 1$ in the greater epithelial ridge is sufficient to induce a neuronal fate (Puligilla et al. 2010).

Despite the lineage relationship between the neurons and the maculae, there is no direct evidence that the organ of Corti and the three cristae are derived from the same lineage progenitors as the maculae. Taken at face value, these lineage results suggest that there could be an early subdivision of the NSD into a neural-sensory macula domain and other sensory compartments comprising the organ of Corti and three cristae. The early expression of $B m p 4$ only in the prospective cristae also supports the notion of an early subdivision within the NSD (Morsli et al. 1998).

\section{FORMATION OF SEMICIRCULAR CANALS AND CRISTAE}

\subsection{Extrinsic Signaling}

The three sensory cristae and their associated semicircular canals constitute the apparatus for detecting angular head movements. Based on the Wnt1/Wnt3a double-mutant phenotypes, Wnts from the dorsal hindbrain are important extrinsic signals for canal and crista formation (Fig. 4) (Riccomagno et al. 2005). Dlx5 is one of the downstream genes that respond to Wnt signaling, and the lack of Dlx5 affects canal and crista formation (Acampora et al. 1999; Depew et al. 1999; Merlo et al. 2002; Riccomagno et al. 2005). On the other hand, $H m x 3$, which is also required for canal formation (Hadrys et al. 1998; Wang et al. 1998, 2004), appears to be regulated by FGF rather than Wnt signaling (Riccomagno et al. 2005; Urness et al. 2010).

Shh from the ventral hindbrain and notochord also seems to be required for canal formation because the lateral canal is missing and the shape of the anterior and posterior canals is abnormal in Shh ${ }^{-/-}$mutants (Fig. 4). However, more recent data suggest that this requirement of Shh for canal formation is a secondary effect, because inner ears of mice with conditional knockout of Smoothened within the otic epithelium have normal canals (Brown and Epstein 2011).

The mesenchyme surrounding the developing inner ear is important for shaping the canals, although the mechanisms involved are largely unexplored. Surgical manipulations in ovo wherein posterior otic mesenchyme is replaced with anteriorly derived mesenchyme resulted in inner ears with a posterior canal and cristae with anterior characteristics (Liang et al. 2010). Conversely, otic cups surrounded by only posterior otic mesenchyme sometimes develop as inner ears in which the anterior canal has posterior characteristics (Liang et al. 2010). Although the molecules involved are not known, studies in mice have implicated several mesenchymal genes in canal formation, such as
Pou3f4 (also known as Brn4) and Prx (ten Berge et al. 1998; Phippard et al. 1999; Sobol et al. 2005).

\subsection{Patterning of the Canals and Cristae}

The three canals and their cristae are derived from two evaginations of the otocyst, the vertical and horizontal canal pouches (Fig. 1). The vertical canal pouch gives rise to the anterior and posterior canals, and the horizontal canal pouch forms the lateral canal. As the canal pouches increase in size, the opposing epithelia in the center portion of the structures merge toward each other and form a fusion plate. Cells forming the fusion plate eventually are resorbed (Fig. 6) (Martin and Swanson 1993), and as a result, the remaining edge of the pouch develops into a tube-shaped canal. The common crus, a connecting structure between the anterior and posterior canals, also forms as a result of this resorption process (Figs. 1 and 6).

Fate mapping the rim of the vertical canal pouch in chicken embryos using lipophilic dyes suggested that a majority of the cells contributing to the canals originated in an area adjacent to the presumptive cristae, thus named the canal genesis zone (Fig. 6, dark blue) (Chang et al. 2004). Most of the cells in the canal pouch proper give rise to the common crus or disappear during resorption (Fig. 6, light blue). This unusual pattern of growth may be the mechanism by which a sensory tissue, the crista, dictates formation of its functionally associated nonsensory component, the canal. Although the hypothesis that sensory tissues induce formation of nonsensory structures is gaining support (Cantos et al. 2000), understanding of the molecular pathways involved remains incomplete. It is believed to involve $\mathrm{Fg} f$ genes and Bmp4 emanating from the presumptive cristae and Bmp2, which is expressed in the canal genesis zone (Chang et al. 1999, 2004, 2008; Gerlach et al. 2000). More recent data show that the vertical canal pouch responds to BMP signaling by changing the cells on its dorsolateral wall from a columnar to a squamous shape, thus expanding and increasing the size of the pouch (Ohta et al. 2010). Whether these cells respond to BMP signaling secreted from the hindbrain or within the otic epithelium, or both, is not clear. Furthermore, the molecular mechanism of the resorption process is also poorly understood, even though genes such as Netrin 1 and Fgf9 are involved (Salminen et al. 2000; Pirvola et al. 2004).

Considering the complexity of this developmental process and the many genes that are involved in the regulation of canal formation, it is often difficult to pinpoint specific roles for those genes based on phenotypes alone (Chang et al. 2003). For example, the lack of proper crista specification will certainly affect canal formation (Kiernan et al. 2005; Chang et al. 2008). Failure to specify the canal pouch 


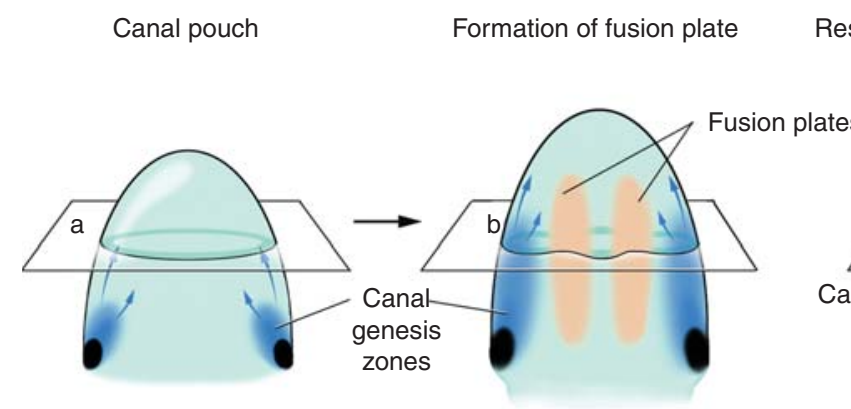

Resorption and continued growth of canal
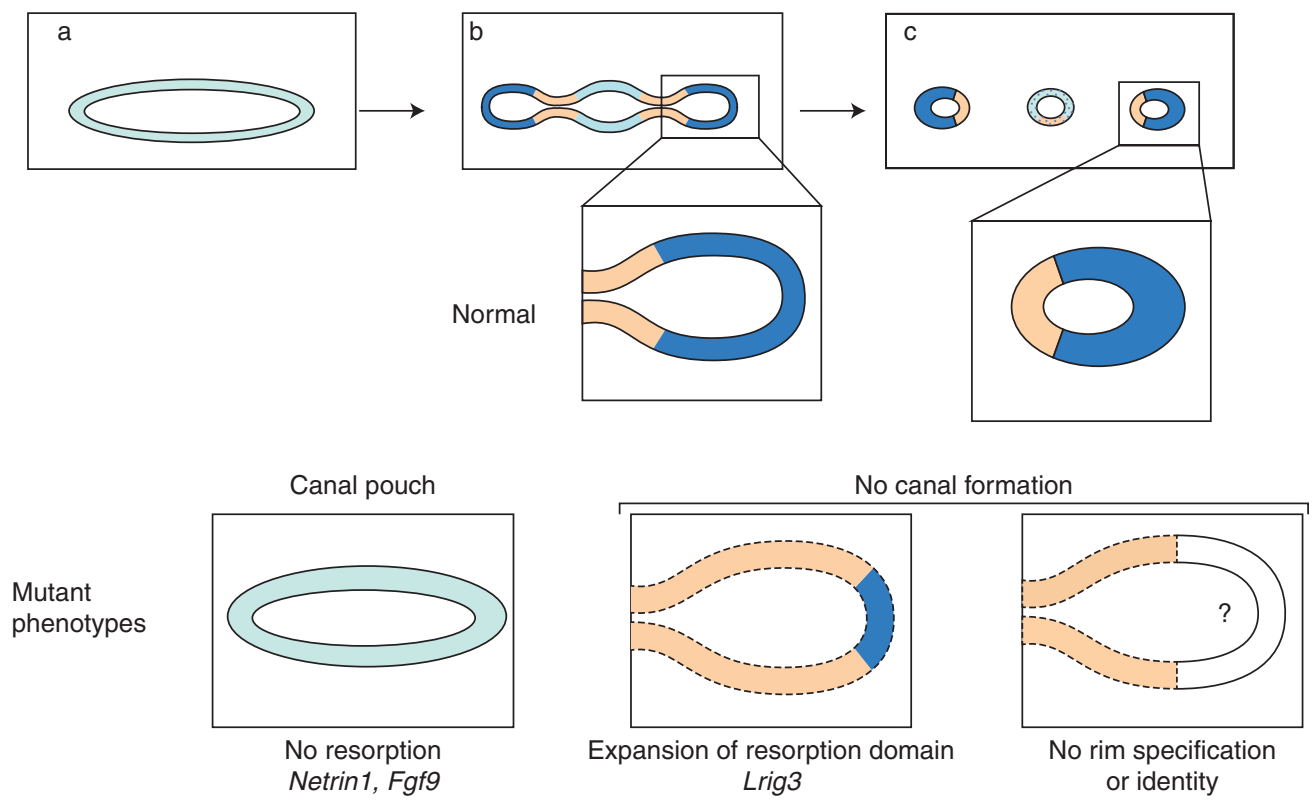

Figure 6. Model of semicircular canal formation. The growth of the canal pouch is promoted by a canal genesis zone (dark blue area), which is induced by the presumptive cristae (black circles). The canal genesis zone gives rise to most of the cells in the canals (blue) and some cells within the common crus (blue dots). The center region of each prospective canal ( $\tan$ ) forms a fusion plate that resorbs, leaving behind two canals joined by the common crus. The bottom panel shows examples of a number of mutant phenotypes. Failure to induce proper growth of the canal pouch or in specification of the resorption domain can result in only a canal pouch, such as in Netrin1 and Fgf9 mutants. Expansion of the resorption domain, as in the case of Lrig3 nulls, or failure to specify the rim of the canal pouch can lead to absence or truncation of the canal, or possibly a canal with smaller caliber.

or, more specifically, the rim of the canal pouch will also result in the absence of canals (Fig. 6). Furthermore, a reciprocal inhibition between the prospective canal and resorption regions has been shown (Abraira et al. 2008). Lrig3, an immunoglobulin superfamily transmembrane protein, has been shown to negatively regulate Netrin1 expression in the resorption domain. In Netrin1 mutants, Lrig3 expression remains expanded and is not properly restricted to the rim of the canal pouch, suggesting that Netrin1 also negatively regulates Lrig3. Based on this type of reciprocal inhibitory relationship between the rim and center regions of the canal pouch, aberrant regulation of these domains could lead to a range of phenotypes, including no resorption, canal truncation (too much resorption), or canals with larger or smaller calibers. Mice with truncations or thinning of canals commonly display behavioral deficits (Ponnio et al. 2002; Adams et al. 2007; Vervoort et al. 2010). In humans Goldenhar syndrome and superior canal dehiscence are examples of syndromes associated with canal defects of unknown etiology; further work elucidating canal formation in model organisms may begin to identify the causes of these and other human syndromes.

\section{FORMATION OF THE COCHLEAR DUCT}

\subsection{Extrinsic Factors}

Multiple extrinsic factors govern proper outgrowth and extension of the cochlear duct. One clear example is Shh emanating from the notochord and floor plate. Similar 
ventral phenotypes occur in $S h h^{-/-}$ears and ears in chicken embryos in which the ventral midline has been ablated, including agenesis of the cochlear duct (Riccomagno et al. 2002; Bok et al. 2005). In addition, a later and closer source of Shh from the spiral ganglion has been implicated in restricting the prosensory domain within the developing cochlea (Fig. 7) (Driver et al. 2008). These results also illustrate how primary axial information specification can be subsequently reinforced by other tissue sources of the same or different signaling molecules.

The proper alignment of the hindbrain with the ear rudiment is important for cochlear duct formation (Bok et al. 2007a; Liang et al. 2010). Additionally, it is well established that a mesenchymal contribution to cochlear duct formation is also important (Montcouquiol and Kelley 2003). Two transcription factors, Tbx1 and Pou3f4, of which the latter is expressed only in the otic mesenchyme, have been implicated so far. Lack of Tbx1 or Pou3f4 in the otic mesenchyme can lead to abnormal coiling or shortening of the cochlear duct, and these two pathways have been shown to interact genetically (Phippard et al. 1999; Braunstein et al. 2008, 2009). One possible mediator of these effects is RA, as both of these transcription factors are believed to induce expression of the RA degradation enzyme Cyp26 in the periotic mesenchyme (Braunstein et al. 2009).

\subsection{Formation of the Organ of Corti}

As the cochlear duct extends, it is regionalized into specialized domains such as the organ or Corti, the stria vascularis, and Reissner's membrane. In the mouse, outgrowth of the cochlear duct first becomes evident at approximately E11. Before E12.5 all of the epithelial cells that comprise the floor of the duct have a similar morphology; however, even at these early time points, a subset of cells express the prosensory markers Jag1, Sox2, and Lfng (Fig. 7). Factors that limit expression of prosensory markers to this subset of cells are still not completely understood, but recent results have suggested that both BMP4 and Shh could act to inhibit prosensory formation outside of the longitudinal stripe (Fig. 7) (Driver et al. 2008; Ohyama et al. 2010). Beginning around E13 prosensory cells begin to express p2 $7^{\text {kip1 }}$, a cell cycle inhibitor, in a gradient that begins in the apex of the duct and extends toward the base over approximately a 24-h period (Fig. 7) (Chen and Segil 1999). This wave of expression leads to terminal mitosis within the prosensory domain. Deletion of $\mathrm{p} 27^{\mathrm{kip} 1}$ results in several interesting changes in the development of the cochlea, including an overproduction of both hair cells and supporting cells. Surprisingly, this overproduction of cells leads to deafness, suggesting that more sensory cells do not make a better cochlea.
Soon after expression of $\mathrm{p} 27^{\mathrm{kip} 1}$ reaches the base of the cochlear duct, the first signs of cellular differentiation, which extends in an opposite gradient to the wave of cell cycle exit, begins in the base of the duct and extends toward the apex (Anniko 1983).

\subsection{Role of Atoh1 in Hair Cell Formation}

The earliest known gene expressed in the prosensory domain eventually associated with sensory hair cells is the bHLH transcription factor Atohl, which is first detected as a gradient that is strongest near the cochlear base and over time extends toward the apex (Anniko 1983; Lanford et al. 2000). As development proceeds, Atoh1 expression is restricted to cells that will develop as hair cells. Although the targets of Atoh1 in developing hair cells are largely unknown, Atoh1 is known to bind to its own promoter region to initiate a positive-feedback loop that will act to maintain or increase expression of the gene (Helms et al. 2000). Recent work using new techniques to assess gene expression and Atoh1-DNA interactions in both the cerebellum and dorsal spinal cord has led to the generation of "Atoh1 targetomes" (Klisch et al. 2011; Lai et al. 2011) that include genes such as Barhl1 and Hes6 that are expressed in hair cells; however, whether Atoh1 acts to directly regulate these genes within the inner ear remains to be determined. Considering the importance of regulating the number of cells that develop as hair cells, it is likely that multiple levels of regulatory control determine how many cells will express Atoh1.

Several factors that positively or negatively regulate Atoh1 have been identified. Sox2, which is expressed in all prosensory regions, is required for Atoh 1 expression. However, Sox 2 also seems to negatively regulate Atoh1, as prolonged expression of Sox 2 inhibits the ability of Atoh1 to induce hair cell formation, whereas decreased expression of Sox2 leads to an increase in hair cell formation (Dabdoub et al. 2008). Recent studies in cell lines have suggested that the canonical Wnt signaling pathway can act to induce Atoh1 expression as a result of direct binding to a Tcf/ Lef-binding site within the Atohl promoter region (Shi et al. 2010). Although not confirmed in the inner ear, these results would suggest that Wnt signaling acts as a positive regulator of Atoh1 expression.

Other regulators of Atohl are the Ids (inhibitors of differentiation), a family of bHLH-related genes that act as antagonists of other bHLH genes (Norton 2000). Three of the four mammalian Id genes, $I d 1, I d 2$, and $I d 3$, are broadly expressed in the developing cochlear duct but become down-regulated in cells that will develop as hair cells (Jones et al. 2006). Moreover, forced persistent expression of $I d 3$ leads to an inhibition of hair cell formation, indicating that Ids act to negatively regulate Atohl. 
D.K. Wu and M.W. Kelley

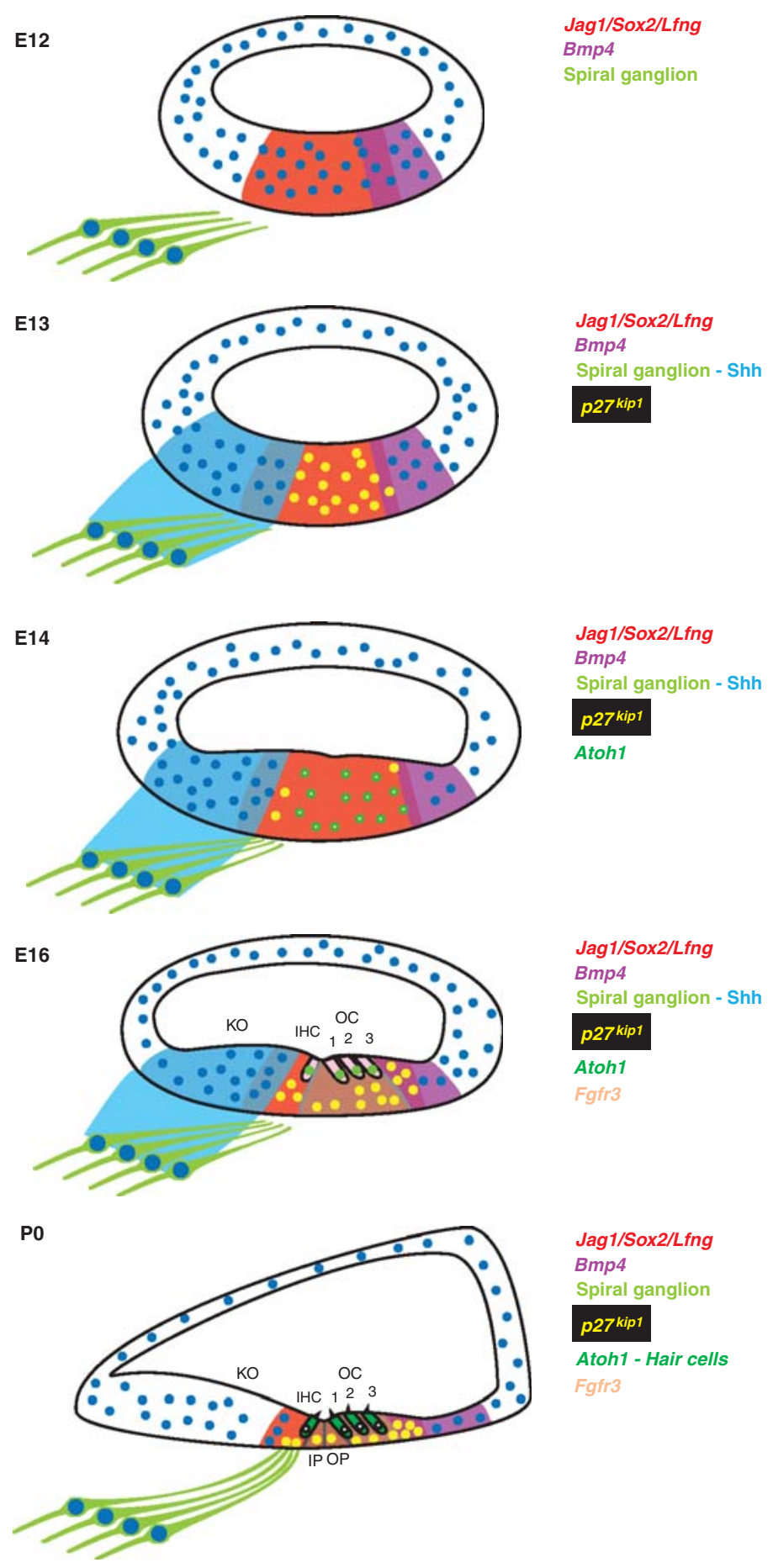

Figure 7. Development of the cochlear duct. Schematic cross sections through the base of the cochlear duct at the indicated ages. At E12 the prosensory domain, as defined by expression of Jag1/Sox2/Lfng, is already present, as is a domain of expression of Bmp4 located at the lateral edge of the duct. There is limited overlap between the two domains. In addition, developing spiral ganglion neurons are located near the medial edge of the duct. At E13 developing spiral ganglion neurons begin to express Sonic hedgehog (Shh), which is believed to diffuse into the medial side of the duct, and $p 27^{k i p 1}$ is expressed in a subset of the Jag1/Sox2/Lfng-positive cells. BMP4 and Shh are believed to restrict sensory formation to the middle of the duct. At E14 Atoh1 expression begins in a subset of the $p 27^{k i p 1}$-positive cells. By E16 Atoh1 expression is resolved to hair cells, and Fgfr 3 is expressed in developing pillar and Deiters' cells. At postnatal day 0 (P0), cellular patterning is essentially complete. Atoh1-positive hair cells are surrounded by supporting cells and spiral ganglion neurons no longer express Shh. Abbreviations: IHC, inner hair cells; IP, inner pillar cell; KO, Kolliker's organ; OC, organ of Corti; OP, outer pillar cell. 
The best-characterized pathway involved in the regulation of hair cell development and Atoh1 expression is the Notch signaling pathway. Notch receptors and their ligands are both transmembrane proteins and therefore can only bind in cells that are directly in contact with one another. Classic work in Drosophila described a signaling loop in which the onset of expression of a proneural bHLH molecule leads to expression of a Notch ligand, which binds to the Notch receptor in neighboring cells, leading to expression of members of a family of inhibitory bHLHs, which then prevent expression of the original proneural bHLH within that cell (Fiuza and Arias 2007). Using this signaling pathway, equipotent progenitor cells can be sorted into the multiple cell types that are required to generate most organs or tissues.

Within the inner ear, localization studies showed expression of Notch1 throughout the epithelium and expression of two Notch ligands, Jagged2 and Delta-like1, in developing hair cells (Lanford et al. 1999; Morrison et al. 1999). Moreover, several inhibitory bHLHs, including Hes5 and Heyl, are expressed in developing supporting cells (Lanford et al. 2000; Zine et al. 2001; Hayashi et al. 2008; Doetzlhofer et al. 2009). Deletion of different members of the pathway results in varying increases in the number of hair cells, an effect that is very consistent with classic Notch-mediated lateral inhibition (Lanford et al. 1999; Zine et al. 2001; Kiernan et al. 2006).

\subsection{Development of Supporting Cells}

All inner ear sensory epithelia contain both hair cells and supporting cells. Whereas hair cells have very distinct morphologies and act in many ways like neurons, supporting cells are like glia: They surround and support the hair cells. However, the nature and developmental regulation of supporting cells is less well understood in comparison with hair cells. In vestibular structures supporting cells appear very similar to unspecialized epithelial cells, whereas in the cochlea they take on several unique morphologies, including pillar cells and Deiters' cells. Experiments in which ectopic hair cells are formed in nonsensory regions of the ear show that hair cells generate signals, as yet unidentified, that induce support cell formation (Woods et al. 2004). In terms of the formation of the pillar cells, the unique cell types that give rise to the tunnel of Corti, the FGF signaling pathway has been shown to regulate both the number and position of these cells. Before pillar cell formation, Fgfr 3 is expressed in the population of cochlear progenitor cells that will develop as pillar cells, outer hair cells, and Deiters' cells (Fig. 7) (Mueller et al. 2002; Jacques et al. 2007). At the same time, developing inner hair cells express FGF8, a ligand with a strong binding affinity for FGFR3. Deletion of either Fgf8 or Fgfr3 leads to a defect in pillar cell development, whereas deletion of Sprouty2, a molecule that has been shown to act as an FGF antagonist and is expressed in the cochlea, leads to an overproduction of pillar cells (Shim et al. 2005). These results are consistent with the hypothesis that FGF8 secreted by inner hair cells binds to and activates FGFR3 in adjacent cells, leading to the formation of pillar cells.

In addition to inducing prosensory cells to develop as pillar cells, FGF8/FGFR3 signaling also acts to prevent these same cells from developing as hair cells (Hayashi et al. 2007; Puligilla et al. 2007). This effect is mediated through activation of the inhibitory bHLH Hey2, a gene that is normally regulated through the Notch pathway. Interestingly, deletion of Hey2 alone does not lead to any changes in cell fate, but when Hey2 is deleted along with inhibition of Notch signaling, pillar cells will convert into outer hair cells (Doetzlhofer et al. 2009).

\subsection{MicroRNAs and Cochlear Development}

MicroRNAs (miRNAs), single-stranded RNAs with a length of approximately 21 nucleotides in their active form, have recently been identified as important regulators of many developmental processes, including the inner ear (Soukup et al. 2009; Li and Fekete 2010). miRNAs hybridize with specific RNA sequences in the $3^{\prime}$ untranslated regions (UTRs) of different mRNA transcripts, which leads to inhibition of protein synthesis. Although the sequence of each miRNA can be used to predict which UTRs it will bind to, these predictions are imperfect, making it difficult to identify which genes will be regulated by a particular miRNA. At least 100 miRNAs are expressed in the developing cochlea (Elkan-Miller et al. 2011). Most experimental work has been focused on the miR-183 family, which contains three members, miR-96, miR-182, and miR-183 (Li and Fekete 2010; Weston et al. 2011). Mutations in miR-96 lead to deafness in both humans and mice, with analysis of the Diminuendo (A-to-T change in the seed region of miR-96) mouse indicating an arrest in the maturation of hair cells at about the time of birth (Kuhn et al. 2011). Similar mutations in the seed region of human miR-96 lead to progressive nonsyndromic deafness. Gain-of-function experiments in zebrafish have shown that increased expression of miR-183 family members can lead to enlarged or duplicated otocysts as well as increased numbers of hair cells ( $\mathrm{Li}$ and Fekete 2010). The specific genes within the inner ear that are regulated by miR- 96 or miR-183 have not been determined yet. Approximately 700 genes contain UTR sequences that are a perfect match to the miR-96 seed region, but only five, Aqp5, Celsr2, Myrip, Odf2, and Ryk, have been examined in either humans or mice. And only 
two of these genes, Aqp5 and Celsr2, were up-regulated in cochlear tissue from mutant mice (Lewis et al. 2009). Therefore, although the mechanisms for these changes are not yet clear, the results clearly demonstrate important roles for miRNAs in regulating inner ear development.

\subsection{Planar Cell Polarity in the Inner Ear}

One of the most striking aspects of the mammalian cochlea, or any other hair cell epithelia, is the uniform orientation of stereociliary bundles. In the cochlea all stereociliary bundles are oriented toward the lateral edge of the epithelium, whereas vestibular epithelia typically contain a reversal zone in which the orientation of the bundles rotates by $180^{\circ}$ (Fig. $8 \mathrm{~A}, \mathrm{~B}$ ). The uniform alignment of a cellular structure within a plane of epithelial cells is referred to as planar cell polarity (PCP). PCP has been studied extensively in Drosophila development; however, the inner ear represents one, if not the best, example of PCP within a vertebrate system. All epithelial cells, including developing hair cells, have a single true cilium located on their lumenal surface. As stereociliary bundle development begins, this cilium, also known as the kinocilium, begins to migrate from the center of the lumenal surface toward the cell's outer edge (Fig. 8C). The direction of this migration typically approximates the final orientation of the bundle, usually within $45^{\circ}$ of the final orientation (Cotanche and Corwin 1991; Denman-Johnson and Forge 1999). As the kinocilium migrates, adjacently located microvilli begin to extend and form the individual stereocilia within the bundle. By the time the kinocilium reaches the outer edge of the lumenal surface, an immature stereociliary bundle can also be identified.

As mentioned above, a set of core genes has been identified that seem to regulate all instances of PCP in Drosophila. Although mouse mutants for all of these genes are not yet available, data from the existing models clearly demonstrate a role for these factors in stereociliary bundle orientation. Vangl1 and Vangl2, Celsr1, and Fz3 and Fz6 are all transmembrane proteins that when mutated lead to defects in stereociliary bundle orientation (Curtin et al. 2003; Montcouquiol et al. 2003; Wang et al. 2006; Torban et al. 2008); mutations in Dvll to -3 , which are located in the cytoplasm, also disrupt bundle orientation (Etheridge et al. 2008). Protein localization studies have shown asymmetric membrane targeting of Vangl2, Fz3, and Fz6 to the medial membranes of cochlear hair cells, whereas Dvll to -3 are localized to the lateral sides of the same hair cells (Fig. 8D).

Although the asymmetric localization of these proteins is believed to be a crucial step in the determination of PCP, recent results regarding the localization of Prickle2, an additional cytoplasmic core protein, in vestibular sensory
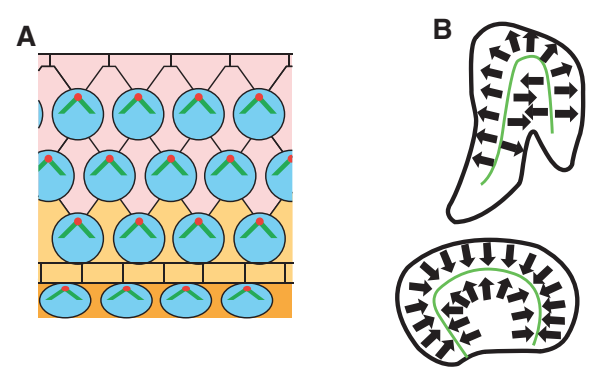

C
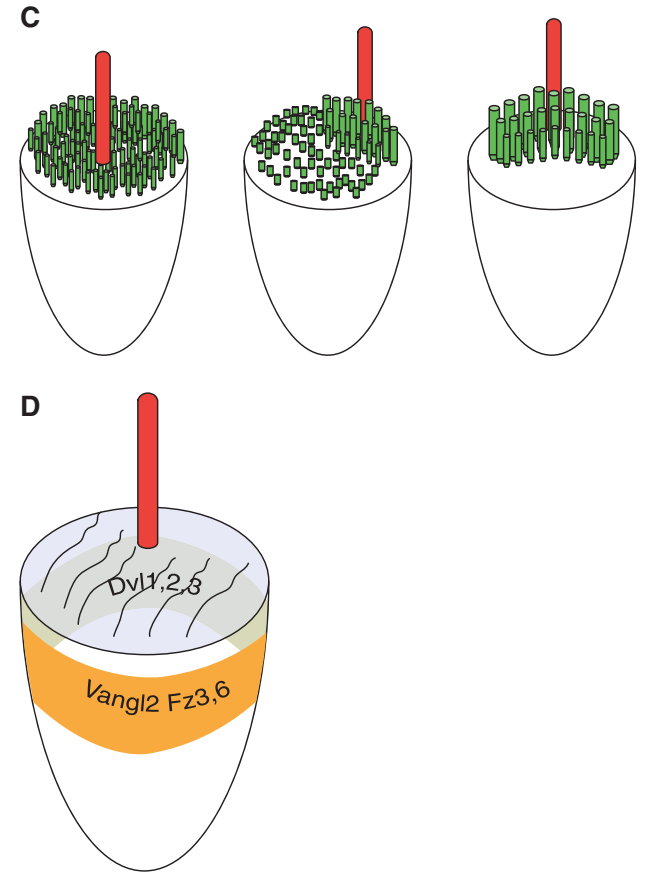

Figure 8. Planar cell polarity in the inner ear. (A) Schematic surface view of the organ of Corti, illustrating the uniform orientation of stereociliary bundles (green) in hair cells (blue). (B) Schematics of the saccule (upper) and utricle (lower) from a mouse. Arrows, orientation of the stereociliary bundles. The striolar reversal zones are marked in green. $(C)$ Development of a stereociliary bundle includes movement of the developing kinocilium (red) from the center of the lumenal surface of the cell toward the outer edge. At the same time a subset of microvilli (green) grows and extends to develop as stereocilia, while other microvilli recede. $(D)$ The PCP molecules Dvl1, -2, and -3 , Vangl2, and Fz3 and -6 become asymmetrically localized to different sides of developing hair cells before the movement of the developing kinocilium to the lateral edge of the lumenal surface. The direction of the kinocilium movement is toward the side of the cell with Dvl1, -2 , and -3 , and away from the side of the cell that contains Vangl2 and Fz3 and -6 .

epithelia have confused this issue somewhat (Deans et al. 2007). Based on the studies described above, a switch in the asymmetric localization of Prickle2 would be predicted to occur at the reversal zone, but this is not the case. Prickle2 is restricted to the same side of the cell across the entire sensory epithelia, even though the orientation of the stereociliary bundles is rotated by $180^{\circ}$. These results show that 
asymmetric localization of PCP proteins is not directly correlated with the location of the stereociliary bundle, and suggest that although localization of PCP proteins indicates inherent cellular asymmetry, this localization may not directly regulate the location of the stereociliary bundle.

Frizzled and Disheveled gene products have been shown to act as receptors (Frizzled) and intracellular mediators (Disheveleds) of the Wnt/wingless (wg) ligands. This has led to the suggestion that Wnts could play a role in regulating PCP in vertebrates, although mutations in $w g$ do not lead to PCP defects in Drosophila. In fact, several recent studies have provided growing evidence for a role for Wnt in PCP. Mutations in Ror2, a Wnt coreceptor, lead to mild inner ear PCP defects, whereas inactivation of Cthrc1, a secreted glycoprotein that modulates Wnt function, genetically interacts with Vangl2 to modulate PCP (Yamamoto et al. 2008). Moreover, in the developing limb Wnt signaling has been shown to lead to the formation of a Ror2/Vangl2 complex that induces a dose-dependent phosphorylation of Vangl2 (Gao et al. 2011). Surprisingly, modulation of Wnt function only leads to minor defects in inner ear PCP, although this may be a result of functional redundancy, as multiple Wnts are expressed within the ear.

In addition to the core PCP genes, several genes that do not regulate PCP in Drosophila have been shown to play a role in PCP in vertebrates. For instance, mutations in Scrb1, a cytoplasmic PDZ protein, and Ptk7, a transmembrane tyrosine kinase, lead to bundle orientation defects in vertebrates (Montcouquiol et al. 2003; Lu et al. 2004). These results suggest that the molecular regulation of PCP is not completely conserved between Drosophila and vertebrates.

Finally, recent work in human genetics has led to the discovery of a new class of syndromic mutations, all of which occur in genes associated with cilia and/or basal bodies (Pan et al. 2005; Lee and Gleeson 2011). As a result, these syndromes are referred to as ciliopathies. Examples include Bardet-Biedl syndrome and nephronophthisis. Analyses of mice or zebrafish with targeted mutations in cilia-related genes have indicated variable defects in stereociliary bundle formation and orientation and in hair cell and auditory function (Ross et al. 2005; Jones et al. 2008). These results are consistent with a role for the kinocilium in the formation of the stereociliary bundle, but the specific function of this structure remains to be determined.

\section{FUTURE DIRECTIONS}

Our understanding of the molecular pathways that regulate patterning and cell-fate decisions in the inner ear has increased significantly in the last decade. Many of the developmentally regulated genes described in this chapter are known to be associated with human hearing loss and they are summarized in table format (Table 1). Readers are referred to more comprehensive reviews on the subject of human deafness genes (Friedman et al. 2003; Leibovici et al. 2008; Dror and Avraham 2009). Nevertheless, many important and outstanding questions remain. How is axial information integrated at the cellular level? What are the crucial molecules that act downstream from Wnt and Shh to specify particular cell fates? Although the initial generation of the three primary axes is largely understood, inner ear development does not proceed autonomously once these axes are established. Continual local signaling is

Table 1. Mammalian genes associated with hearing impairment in humans

\begin{tabular}{|c|c|c|c|}
\hline Genes & $\begin{array}{l}\text { Expression } \\
\text { domains in } \\
\text { mice }\end{array}$ & Human disorders & $\begin{array}{l}\text { Deficits or ear } \\
\text { structures } \\
\text { affected in } \\
\text { humans }\end{array}$ \\
\hline $\begin{array}{c}B b s 1 \text { to } \\
-12\end{array}$ & Ubiquitous & $\begin{array}{l}\text { Bardet-Biedl } \\
\text { syndrome }\end{array}$ & $\begin{array}{l}\text { Sensorineural } \\
\text { hearing loss }\end{array}$ \\
\hline $\begin{array}{l}\text { Eyal, } \\
\qquad \text { Sixl }\end{array}$ & $\begin{array}{l}\text { Sensory, } \\
\text { nonsensory, } \\
\text { mesenchyme, } \\
\text { ganglion }\end{array}$ & $\begin{array}{l}\text { Branchio-oto-renal } \\
\text { and branchio-oto } \\
\text { syndromes }\end{array}$ & $\begin{array}{l}\text { Outer, middle, } \\
\text { and inner ear } \\
\text { malformations }\end{array}$ \\
\hline Fgfr3 & Cochlea & Muenke syndrome & $\begin{array}{l}\text { Sensorineural } \\
\text { hearing loss }\end{array}$ \\
\hline Gata3 & $\begin{array}{l}\text { Vestibule, } \\
\text { cochlea }\end{array}$ & $\begin{array}{l}\text { Hypoparathyroidism, } \\
\text { sensorineural } \\
\text { deafness, renal } \\
\text { anomaly (HDR) } \\
\text { syndrome }\end{array}$ & $\begin{array}{l}\text { Sensorineural } \\
\text { hearing loss }\end{array}$ \\
\hline Gli3 & $\begin{array}{l}\text { Otic epithelium, } \\
\text { periotic } \\
\text { mesenchyme }\end{array}$ & $\begin{array}{l}\text { Pallister-Hall } \\
\text { syndrome }\end{array}$ & $\begin{array}{l}\text { Sensorineural } \\
\text { hearing loss }\end{array}$ \\
\hline Jagged 1 & Sensory organs & Alagille syndrome & $\begin{array}{l}\text { Hearing loss and } \\
\text { vestibular } \\
\text { pathology }\end{array}$ \\
\hline $\operatorname{miR}-96$ & Cochlea & $\begin{array}{l}\text { Progressive } \\
\text { sensorineural } \\
\text { hearing loss }\end{array}$ & $\begin{array}{l}\text { Sensorineural } \\
\text { hearing loss }\end{array}$ \\
\hline Noggin & $\begin{array}{l}\text { Periotic } \\
\text { mesenchyme, } \\
\text { cochlear duct }\end{array}$ & $\begin{array}{l}\text { Proximal } \\
\text { symphalangism, } \\
\text { multiple synotosis }\end{array}$ & $\begin{array}{l}\text { Conductive } \\
\text { hearing loss }\end{array}$ \\
\hline Pax2 & $\begin{array}{l}\text { Sensory organs, } \\
\text { cochlea }\end{array}$ & $\begin{array}{l}\text { Renal coloboma } \\
\text { syndrome }\end{array}$ & $\begin{array}{l}\text { Sensorineural } \\
\text { hearing loss }\end{array}$ \\
\hline Sox2 & $\begin{array}{l}\text { Neural-sensory } \\
\text { domain, } \\
\text { sensory } \\
\text { organs, } \\
\text { ganglion }\end{array}$ & $\begin{array}{l}\text { Anophthalamia, } \\
\text { hearing loss, brain } \\
\text { anomalies }\end{array}$ & $\begin{array}{l}\text { Sensorineural } \\
\text { hearing loss }\end{array}$ \\
\hline$T b x 1$ & $\begin{array}{l}\text { Cristae and } \\
\text { nonsensory } \\
\text { structures of } \\
\text { the inner ear, } \\
\text { periotic } \\
\text { mesenchyme }\end{array}$ & DiGeorge syndrome & $\begin{array}{l}\text { Outer, middle, } \\
\text { and inner ear } \\
\text { malformations }\end{array}$ \\
\hline
\end{tabular}


required for reinforcement and refinement of positional identity and patterning. For example, Shh arising from the ventral midline is required for initial cochlear duct formation, whereas at later time points expression of Shh by the developing spiral ganglion neurons acts to pattern different aspects of the cochlear duct. However, the downstream pathways that are mediated by Shh are largely unknown.

Our understanding of how progenitors become specified as hair cells or supporting cells is still limited, as are the factors that generate the diversity of cell types within the inner ear. Within the cochlear duct, it is still not clear how the organ of Corti is restricted to a narrow stripe of cells, or how outgrowth of the duct correlates with cellular pattern. Finally, because of the directional nature of the stereociliary bundle, uniform orientation of these bundles (PCP) plays a crucial role in the function of the auditory and vestibular systems. Although some of the genetic factors that regulate this process have been identified, an understanding of how the protein products of these genes act to physically direct the stereociliary bundle to specific locations on the surface of each hair cell remains to be determined.

\section{ACKNOWLEDGMENTS}

We thank Dr. Douglas Epstein for providing pictures for Figure 5 and sharing his accepted manuscript prior to publication, and our laboratory members Drs. Steven Raft and Elizabeth Driver for critical reading of the manuscript.

\section{REFERENCES}

Abello G, Khatri S, Radosevic M, Scotting PJ, Giraldez F, Alsina B. 2010. Independent regulation of Sox 3 and $L m x 1 b$ by FGF and BMP signaling influences the neurogenic and non-neurogenic domains in the chick otic placode. Dev Biol 339: 166-178.

Abraira VE, Del Rio T, Tucker AF, Slonimsky J, Keirnes HL, Goodrich LV. 2008. Cross-repressive interactions between Lrig3 and netrin 1 shape the architecture of the inner ear. Development 135: 40914099.

Acampora D, Merlo GR, Paleari L, Zerega B, Postiglione MP, Mantero S, Bober E, Barbieri O, Simeone A, Levi G. 1999. Craniofacial, vestibular and bone defects in mice lacking the Distal-less-related gene Dlx5. Development 126: 3795-3809.

Adam J, Myat A, Le Roux I, Eddison M, Henrique D, Ish-Horowicz D, Lewis J. 1998. Cell fate choices and the expression of Notch, Delta and Serrate homologues in the chick inner ear: Parallels with Drosophila sense-organ development. Development 125: 4645-4654.

Adams ME, Hurd EA, Beyer LA, Swiderski DL, Raphael Y, Martin DM. 2007. Defects in vestibular sensory epithelia and innervation in mice with loss of Chd7 function: Implications for human CHARGE syndrome. J Comp Neurol 504: 519-532.

Alsina B, Abello G, Ulloa E, Henrique D, Pujades C, Giraldez F. 2004. FGF signaling is required for determination of otic neuroblasts in the chick embryo. Dev Biol 267: 119-134.

Alvarez-Medina R, Cayuso J, Okubo T, Takada S, Marti E. 2008. Wnt canonical pathway restricts graded Shh/Gli patterning activity through the regulation of Gli3 expression. Development 135: 237-247.
Anniko M. 1983. Cytodifferentiation of cochlear hair cells. Am J Otolaryngol 4: 375-388.

Bailey AP, Streit A. 2006. Sensory organs: Making and breaking the preplacodal region. Curr Top Dev Biol 72: 167-204.

Basch ML, Ohyama T, Segil N, Groves AK. 2011. Canonical Notch signaling is not necessary for prosensory induction in the mouse cochlea: Insights from a conditional mutant of RBPjк. J Neurosci 31: 80468058.

Bell D, Streit A, Gorospe I, Varela-Nieto I, Alsina B, Giraldez F. 2008. Spatial and temporal segregation of auditory and vestibular neurons in the otic placode. Dev Biol 322: 109-120.

Bok J, Bronner-Fraser M, Wu DK. 2005. Role of the hindbrain in dorsoventral but not anteroposterior axial specification of the inner ear. Development 132: 2115-2124.

Bok J, Brunet LJ, Howard O, Burton Q, Wu DK. 2007a. Role of hindbrain in inner ear morphogenesis: Analysis of Noggin knockout mice. Dev Biol 311: 69-78.

Bok J, Chang W, Wu DK. 2007b. Patterning and morphogenesis of the vertebrate inner ear. Int J Dev Biol 51: 521-533.

Bok J, Dolson DK, Hill P, Ruther U, Epstein DJ, Wu DK. 2007c. Opposing gradients of Gli repressor and activators mediate Shh signaling along the dorsoventral axis of the inner ear. Development 134: 1713-1722.

Bok J, Raft S, Kong KA, Koo SK, Drager UC, Wu DK. 2011. Transient retinoic acid signaling confers anterior-posterior polarity to the inner ear. Proc Natl Acad Sci 108: 161-166.

Braunstein EM, Crenshaw EBIII, Morrow BE, Adams JC. 2008. Cooperative function of Tbxl and Brn4 in the periotic mesenchyme is necessary for cochlea formation. J Assoc Res Otolaryngol 9: 33-43.

Braunstein EM, Monks DC, Aggarwal VS, Arnold JS, Morrow BE. 2009. $T b x 1$ and Brn4 regulate retinoic acid metabolic genes during cochlear morphogenesis. BMC Dev Biol 9: 31.

Brigande JV, Iten LE, Fekete DM. 2000. A fate map of chick otic cup closure reveals lineage boundaries in the dorsal otocyst. Dev Biol 227: $256-270$.

Brooker R, Hozumi K, Lewis J. 2006. Notch ligands with contrasting functions: Jagged1 and Delta1 in the mouse inner ear. Development 133: $1277-1286$.

Brown AS, Epstein DJ. 2011. Otic ablation of smoothened reveals direct and indirect requirement for Hedgehog signaling in inner ear development. Development 138: 3967-3976.

Cantos R, Cole LK, Acampora D, Simeone A, Wu DK. 2000. Patterning of the mammalian cochlea. Proc Natl Acad Sci 97: 11707-11713.

Chang W, Nunes FD, De Jesus-Escobar JM, Harland R, Wu DK. 1999. Ectopic noggin blocks sensory and nonsensory organ morphogenesis in the chicken inner ear. Dev Biol 216: 369-381.

Chang W, Cole LK, Cantos R, Wu DK. 2003. Molecular genetics of vestibular organ development. In Springer handbook of auditory research: The vestibular system (ed. Highstein SM, et al.), Vol. 19. Springer-Verlag, New York.

Chang W, Brigande JV, Fekete DM, Wu DK. 2004. The development of semicircular canals in the inner ear: Role of FGFs in sensory cristae. Development 131: 4201-4211.

Chang W, Lin Z, Kulessa H, Hebert J, Hogan BL, Wu DK. 2008. Bmp4 is essential for the formation of the vestibular apparatus that detects angular head movements. PLoS Genet 4: e1000050.

Chen P, Segil N. 1999. p2 $7^{\text {Kipl }}$ links cell proliferation to morphogenesis in the developing organ of Corti. Development 126: 1581-1590.

Choo D, Ward J, Reece A, Dou H, Lin Z, Greinwald J. 2006. Molecular mechanisms underlying inner ear patterning defects in kreisler mutants. Dev Biol 289: 308-317.

Cole LK, Le Roux I, Nunes F, Laufer E, Lewis J, Wu DK. 2000. Sensory organ generation in the chicken inner ear: Contributions of bone morphogenetic protein 4, serrate 1, and lunatic fringe. J Comp Neurol 424: 509-520.

Corwin JT, Cotanche DA. 1989. Development of location-specific hair cell stereocilia in denervated embryonic ears. J Comp Neurol 288: $529-537$. 
Cotanche DA, Corwin JT. 1991. Stereociliary bundles reorient during hair cell development and regeneration in the chick cochlea. Hear Res 52: 379-402.

Curtin JA, Quint E, Tsipouri V, Arkell RM, Cattanach B, Copp AJ, Henderson DJ, Spurr N, Stanier P, Fisher EM, et al. 2003. Mutation of Celsrl disrupts planar polarity of inner ear hair cells and causes severe neural tube defects in the mouse. Curr Biol 13: 1129-1133.

Dabdoub A, Puligilla C, Jones JM, Fritzsch B, Cheah KS, Pevny LH, Kelley MW. 2008. Sox 2 signaling in prosensory domain specification and subsequent hair cell differentiation in the developing cochlea. Proc Natl Acad Sci 105: 18396-18401.

Deans MR, Antic D, Suyama K, Scott MP, Axelrod JD, Goodrich LV. 2007. Asymmetric distribution of Prickle-like 2 reveals an early underlying polarization of vestibular sensory epithelia in the inner ear. J Neurosci 27: 3139-3147.

Denman-Johnson K, Forge A. 1999. Establishment of hair bundle polarity and orientation in the developing vestibular system of the mouse. $J$ Neurocytol 28: 821-835.

Depew MJ, Liu JK, Long JE, Presley R, Meneses JJ, Pedersen RA, Rubenstein JL. 1999. Dl $x 5$ regulates regional development of the branchial arches and sensory capsules. Development 126: 3831-3846.

Diez del Corral R, Storey KG. 2004. Opposing FGF and retinoid pathways: A signalling switch that controls differentiation and patterning onset in the extending vertebrate body axis. Bioessays 26: 857-869.

Doetzlhofer A, Basch ML, Ohyama T, Gessler M, Groves AK, Segil N. 2009. Hey2 regulation by FGF provides a Notch-independent mechanism for maintaining pillar cell fate in the organ of Corti. Dev Cell 16: $58-69$.

Driver EC, Pryor SP, Hill P, Turner J, Ruther U, Biesecker LG, Griffith AJ, Kelley MW. 2008. Hedgehog signaling regulates sensory cell formation and auditory function in mice and humans. J Neurosci 28: 7350-7358.

Dror AA, Avraham KB. 2009. Hearing loss: Mechanisms revealed by genetics and cell biology. Annu Rev Genet 43: 411-437.

Elkan-Miller T, Ulitsky I, Hertzano R, Rudnicki A, Dror AA, Lenz DR, Elkon R, Irmler M, Beckers J, Shamir R, et al. 2011. Integration of transcriptomics, proteomics, and microRNA analyses reveals novel microRNA regulation of targets in the mammalian inner ear. PLoS ONE 6: e18195.

Etheridge SL, Ray S, Li S, Hamblet NS, Lijam N, Tsang M, Greer J, Kardos N, Wang J, Sussman DJ, et al. 2008. Murine Dishevelled 3 functions in redundant pathways with Dishevelled 1 and 2 in normal cardiac outflow tract, cochlea, and neural tube development. PLoS Genet 4: e1000259.

Fekete DM. 1996. Cell fate specification in the inner ear. Curr Opin Neurobiol 6: $533-541$.

Fekete DM, Wu DK. 2002. Revisiting cell fate specification in the inner ear. Curr Opin Neurobiol 12: 35-42.

Fiuza UM, Arias AM. 2007. Cell and molecular biology of Notch. $J$ Endocrinol 194: 459-474.

Freter S, Muta Y, Mak SS, Rinkwitz S, Ladher RK. 2008. Progressive restriction of otic fate: The role of FGF and Wnt in resolving inner ear potential. Development 135: 3415-3424.

Freyer L, Morrow BE. 2010. Canonical Wnt signaling modulates Tbx1, Eyal, and Sixl expression, restricting neurogenesis in the otic vesicle. Dev Dyn 239: 1708-1722.

Friedman TB, Schultz JM, Ben-Yosef T, Pryor SP, Lagziel A, Fisher RA, Wilcox ER, Riazuddin S, Ahmed ZM, Belyantseva IA, et al. 2003. Recent advances in the understanding of syndromic forms of hearing loss. Ear Hear 24: 289-302.

Gao B, Song H, Bishop K, Elliot G, Garrett L, English MA, Andre P, Robinson J, Sood R, Minami Y, et al. 2011. Wnt signaling gradients establish planar cell polarity by inducing Vangl2 phosphorylation through Ror2. Dev Cell 20: 163-176.

Gerlach LM, Hutson MR, Germiller JA, Nguyen-Luu D, Victor JC, Barald KF. 2000. Addition of the BMP4 antagonist, noggin, disrupts avian inner ear development. Development 127: 45-54.
Giraldez F. 1998. Regionalized organizing activity of the neural tube revealed by the regulation of $1 \mathrm{mxl}$ in the otic vesicle. Dev Biol 203: 189-200.

Hadrys T, Braun T, Rinkwitz-Brandt S, Arnold HH, Bober E. 1998. Nkx51 controls semicircular canal formation in the mouse inner ear. Development 125: 33-39.

Hammond KL, Loynes HE, Folarin AA, Smith J, Whitfield TT. 2003. Hedgehog signalling is required for correct anteroposterior patterning of the zebrafish otic vesicle. Development 130: 1403-1417.

Hammond KL, van Eeden FJ, Whitfield TT. 2010. Repression of Hedgehog signalling is required for the acquisition of dorsolateral cell fates in the zebrafish otic vesicle. Development 137: 1361-1371.

Hayashi T, Cunningham D, Bermingham-McDonogh O. 2007. Loss of FGFR3 leads to excess hair cell development in the mouse organ of Corti. Dev Dyn 236: 525-533.

Hayashi T, Kokubo H, Hartman BH, Ray CA, Reh TA, BerminghamMcDonogh O. 2008. Hesr1 and Hesr2 may act as early effectors of Notch signaling in the developing cochlea. Dev Biol 316: 87-99.

Helms AW, Abney AL, Ben-Arie N, Zoghbi HY, Johnson JE. 2000. Autoregulation and multiple enhancers control Math1 expression in the developing nervous system. Development 127: 1185-1196.

Jacques BE, Montcouquiol ME, Layman EM, Lewandoski M, Kelley MW. 2007. Fgf8 induces pillar cell fate and regulates cellular patterning in the mammalian cochlea. Development 134: 3021-3029.

Jayasena CS, Ohyama T, Segil N, Groves AK. 2008. Notch signaling augments the canonical Wnt pathway to specify the size of the otic placode. Development 135: 2251-2261.

Jones JM, Montcouquiol M, Dabdoub A, Woods C, Kelley MW. 2006. Inhibitors of differentiation and DNA binding (Ids) regulate Math1 and hair cell formation during the development of the organ of Corti. $J$ Neurosci 26: 550-558.

Jones C, Roper VC, Foucher I, Qian D, Banizs B, Petit C, Yoder BK, Chen P. 2008. Ciliary proteins link basal body polarization to planar cell polarity regulation. Nat Genet 40: 69-77.

Kiernan AE, Pelling AL, Leung KK, Tang AS, Bell DM, Tease C, LovellBadge R, Steel KP, Cheah KS. 2005. Sox2 is required for sensory organ development in the mammalian inner ear. Nature 434: 1031-1035.

Kiernan AE, Xu J, Gridley T. 2006. The Notch ligand JAG1 is required for sensory progenitor development in the mammalian inner ear. PLoS Genet 2: e4.

Klisch TJ, Xi Y, Flora A, Wang L, Li W, Zoghbi HY. 2011. In vivo Atoh1 targetome reveals how a proneural transcription factor regulates cerebellar development. Proc Natl Acad Sci 108: 3288-3293.

Koo SK, Hill JK, Hwang CH, Lin ZS, Millen KJ, Wu DK. 2009. Lmxla maintains proper neurogenic, sensory, and non-sensory domains in the mammalian inner ear. Dev Biol 333: 14-25.

Koundakjian EJ, Appler JL, Goodrich LV. 2007. Auditory neurons make stereotyped wiring decisions before maturation of their targets. J Neurosci 27: $14078-14088$

Kuhn S, Johnson SL, Furness DN, Chen J, Ingham N, Hilton JM, Steffes G, Lewis MA, Zampini V, Hackney CM, et al. 2011. miR-96 regulates the progression of differentiation in mammalian cochlear inner and outer hair cells. Proc Natl Acad Sci 108: 2355-2360.

Ladher RK, Anakwe KU, Gurney AL, Schoenwolf GC, Francis-West PH. 2000. Identification of synergistic signals initiating inner ear development. Science 290: 1965-1967.

Lai HC, Klisch TJ, Roberts R, Zoghbi HY, Johnson JE. 2011. In vivo neuronal subtype-specific targets of Atoh1 (Math1) in dorsal spinal cord. J Neurosci 31: 10859-10871.

Lanford PJ, Lan Y, Jiang R, Lindsell C, Weinmaster G, Gridley T, Kelley MW. 1999. Notch signalling pathway mediates hair cell development in mammalian cochlea. Nat Genet 21: 289-292.

Lanford PJ, Shailam R, Norton CR, Gridley T, Kelley MW. 2000. Expression of Math1 and HES5 in the cochleae of wildtype and Jag2 mutant mice. J Assoc Res Otolaryngol 1: 161-171.

Lawoko-Kerali G, Rivolta MN, Lawlor P, Cacciabue-Rivolta DI, LangtonHewer C, van Doorninck JH, Holley MC. 2004. GATA3 and NeuroD 
distinguish auditory and vestibular neurons during development of the mammalian inner ear. Mech Dev 121: 287-299.

Lee JE, Gleeson JG. 2011. Cilia in the nervous system: Linking cilia function and neurodevelopmental disorders. Curr Opin Neurol 24: $98-105$.

Leibovici M, Safieddine S, Petit C. 2008. Mouse models for human hereditary deafness. Curr Top Dev Biol 84: 385-429.

Lewis MA, Quint E, Glazier AM, Fuchs H, De Angelis MH, Langford C, van Dongen S, Abreu-Goodger C, Piipari M, Redshaw N, et al. 2009. An ENU-induced mutation of miR-96 associated with progressive hearing loss in mice. Nat Genet 41: 614-618.

Li H, Fekete DM. 2010. MicroRNAs in hair cell development and deafness. Curr Opin Otolaryngol Head Neck Surg 18: 459-465.

Li CW, Van De Water TR, Ruben RJ. 1978. The fate mapping of the eleventh and twelfth day mouse otocyst: An in vitro study of the sites of origin of the embryonic inner ear sensory structures. J Morphol 157: 249-267.

Liang JK, Bok J, Wu DK. 2010. Distinct contributions from the hindbrain and mesenchyme to inner ear morphogenesis. Dev Biol 337: 324-334.

Lin Z, Cantos R, Patente M, Wu DK. 2005. Gbx2 is required for the morphogenesis of the mouse inner ear: A downstream candidate of hindbrain signaling. Development 132: 2309-2318.

Lu X, Borchers AG, Jolicoeur C, Rayburn H, Baker JC, Tessier-Lavigne M. 2004. PTK7/CCK-4 is a novel regulator of planar cell polarity in vertebrates. Nature 430: 93-98.

Ma Q, Chen Z, del Barco Barrantes I, de la Pompa JL, Anderson DJ. 1998. neurogenin 1 is essential for the determination of neuronal precursors for proximal cranial sensory ganglia. Neuron 20: 469-482.

Ma Q, Anderson DJ, Fritzsch B. 2000. Neurogenin 1 null mutant ears develop fewer, morphologically normal hair cells in smaller sensory epithelia devoid of innervation. J Assoc Res Otolaryngol 1: 129-143.

MacLean G, Abu-Abed S, Dolle P, Tahayato A, Chambon P, Petkovich M. 2001. Cloning of a novel retinoic-acid metabolizing cytochrome P450, Cyp26B1, and comparative expression analysis with Cyp26A1 during early murine development. Mech Dev 107: 195-201.

Marklund M, Sjodal M, Beehler BC, Jessell TM, Edlund T, Gunhaga L. 2004. Retinoic acid signalling specifies intermediate character in the developing telencephalon. Development 131: 4323-4332.

Martin P, Swanson GJ. 1993. Descriptive and experimental analysis of the epithelial remodellings that control semicircular canal formation in the developing mouse inner ear. Dev Biol 159: 549-558.

Merlo GR, Paleari L, Mantero S, Zerega B, Adamska M, Rinkwitz S, Bober E, Levi G. 2002. The Dlx5 homeobox gene is essential for vestibular morphogenesis in the mouse embryo through a BMP4-mediated pathway. Dev Biol 248: 157-169.

Montcouquiol M, Kelley MW. 2003. Planar and vertical signals control cellular differentiation and patterning in the mammalian cochlea. $J$ Neurosci 23: 9469-9478.

Montcouquiol M, Rachel RA, Lanford PJ, Copeland NG, Jenkins NA, Kelley MW. 2003. Identification of Vangl2 and Scrb1 as planar polarity genes in mammals. Nature 423: 173-177.

Morrison A, Hodgetts C, Gossler A, Hrabe de Angelis M, Lewis J. 1999. Expression of Delta1 and Serrate1 (Jagged1) in the mouse inner ear. Mech Dev 84: 169-172.

Morsli H, Choo D, Ryan A, Johnson R, Wu DK. 1998. Development of the mouse inner ear and origin of its sensory organs. J Neurosci 18: $3327-3335$.

Mueller KL, Jacques BE, Kelley MW. 2002. Fibroblast growth factor signaling regulates pillar cell development in the organ of Corti. J Neurosci 22: 9368-9377.

Murdoch JN, Copp AJ. 2010. The relationship between sonic Hedgehog signaling, cilia, and neural tube defects. Birth Defects Res A Clin Mol Teratol 88: 633-652.

Norton JD. 2000. ID helix-loop-helix proteins in cell growth, differentiation and tumorigenesis. J Cell Sci 113: 3897-3905.
Ohta S, Mansour SL, Schoenwolf GC. 2010. BMP/SMAD signaling regulates the cell behaviors that drive the initial dorsal-specific regional morphogenesis of the otocyst. Dev Biol 347: 369-381.

Ohyama T, Mohamed OA, Taketo MM, Dufort D, Groves AK. 2006. Wnt signals mediate a fate decision between otic placode and epidermis. Development 133: 865-875.

Ohyama T, Basch ML, Mishina Y, Lyons KM, Segil N, Groves AK. 2010. BMP signaling is necessary for patterning the sensory and nonsensory regions of the developing mammalian cochlea. J Neurosci 30: 1504415051.

Ozaki H, Nakamura K, Funahashi J, Ikeda K, Yamada G, Tokano H, Okamura HO, Kitamura K, Muto S, Kotaki H, et al. 2004. Sixl controls patterning of the mouse otic vesicle. Development 131: 551-562.

Pan J, Wang Q, Snell WJ. 2005. Cilium-generated signaling and ciliarelated disorders. Lab Invest 85: 452-463.

Parr BA, Shea MJ, Vassileva G, McMahon AP. 1993. Mouse Wnt genes exhibit discrete domains of expression in the early embryonic CNS and limb buds. Development 119: 247-261.

Phillips BT, Storch EM, Lekven AC, Riley BB. 2004. A direct role for Fgf but not Wnt in otic placode induction. Development 131: 923-931.

Phippard D, Lu L, Lee D, Saunders JC, Crenshaw EBIII. 1999. Targeted mutagenesis of the POU-domain gene Brn4/Pou3f4 causes developmental defects in the inner ear. J Neurosci 19: 5980-5989.

Pirvola U, Zhang X, Mantela J, Ornitz DM, Ylikoski J. 2004. Fgf9 signaling regulates inner ear morphogenesis through epithelial-mesenchymal interactions. Dev Biol 273: 350-360.

Ponnio T, Burton Q, Pereira FA, Wu DK, Conneely OM. 2002. The nuclear receptor Nor-1 is essential for proliferation of the semicircular canals of the mouse inner ear. Mol Cell Biol 22: 935-945.

Puligilla C, Feng F, Ishikawa K, Bertuzzi S, Dabdoub A, Griffith AJ, Fritzsch B, Kelley MW. 2007. Disruption of fibroblast growth factor receptor 3 signaling results in defects in cellular differentiation, neuronal patterning, and hearing impairment. Dev Dyn 236: 1905-1917.

Puligilla C, Dabdoub A, Brenowitz SD, Kelley MW. 2010. Sox2 induces neuronal formation in the developing mammalian cochlea. J Neurosci 30: $714-722$.

Radosevic M, Robert-Moreno A, Coolen M, Bally-Cuif L, Alsina B. 2011. Her9 represses neurogenic fate downstream of Tbx 1 and retinoic acid signaling in the inner ear. Development 138: 397-408.

Raft S, Nowotschin S, Liao J, Morrow BE. 2004. Suppression of neural fate and control of inner ear morphogenesis by Tbx1. Development 131: $1801-1812$.

Raft S, Koundakjian EJ, Quinones H, Jayasena CS, Goodrich LV, Johnson JE, Segil N, Groves AK. 2007. Cross-regulation of Ngn1 and Math1 coordinates the production of neurons and sensory hair cells during inner ear development. Development 134: 4405-4415.

Reijntjes S, Gale E, Maden M. 2004. Generating gradients of retinoic acid in the chick embryo: Cyp26C1 expression and a comparative analysis of the Cyp26 enzymes. Dev Dyn 230: 509-517.

Ribes V, Briscoe J. 2009. Establishing and interpreting graded Sonic Hedgehog signaling during vertebrate neural tube patterning: The role of negative feedback. Cold Spring Harb Perspect Biol 1: a002014.

Riccomagno MM, Martinu L, Mulheisen M, Wu DK, Epstein DJ. 2002. Specification of the mammalian cochlea is dependent on Sonic hedgehog. Genes Dev 16: 2365-2378.

Riccomagno MM, Takada S, Epstein DJ. 2005. Wnt-dependent regulation of inner ear morphogenesis is balanced by the opposing and supporting roles of Shh. Genes Dev 19: 1612-1623.

Ross AJ, May-Simera H, Eichers ER, Kai M, Hill J, Jagger DJ, Leitch CC, Chapple JP, Munro PM, Fisher S, et al. 2005. Disruption of BardetBiedl syndrome ciliary proteins perturbs planar cell polarity in vertebrates. Nat Genet 37: 1135-1140.

Salminen M, Meyer BI, Bober E, Gruss P. 2000. Netrin 1 is required for semicircular canal formation in the mouse inner ear. Development 127: $13-22$. 
Satoh T, Fekete DM. 2005. Clonal analysis of the relationships between mechanosensory cells and the neurons that innervate them in the chicken inner ear. Development 132: 1687-1697.

Schlosser G. 2006. Induction and specification of cranial placodes. Dev Biol 294: 303-351.

Shi F, Cheng YF, Wang XL, Edge AS. 2010. $\beta$-Catenin up-regulates Atoh1 expression in neural progenitor cells by interaction with an Atoh1 $3^{\prime}$ enhancer. J Biol Chem 285: 392-400.

Shim K, Minowada G, Coling DE, Martin GR. 2005. Sprouty2, a mouse deafness gene, regulates cell fate decisions in the auditory sensory epithelium by antagonizing FGF signaling. Dev Cell 8: 553-564.

Sirbu IO, Gresh L, Barra J, Duester G. 2005. Shifting boundaries of retinoic acid activity control hindbrain segmental gene expression. Development 132: 2611-2622.

Sobol SE, Teng X, Crenshaw EBIII. 2005. Abnormal mesenchymal differentiation in the superior semicircular canal of Brn4/Pou3f4 knockout mice. Arch Otolaryngol Head Neck Surg 131: 41-45.

Soukup GA, Fritzsch B, Pierce ML, Weston MD, Jahan I, McManus MT, Harfe BD. 2009. Residual microRNA expression dictates the extent of inner ear development in conditional Dicer knockout mice. Dev Biol 328: $328-341$.

Swanson GJ, Howard M, Lewis J. 1990. Epithelial autonomy in the development of the inner ear of a bird embryo. Dev Biol 137: 243-257.

Tahayato A, Dolle P, Petkovich M. 2003. Cyp26C1 encodes a novel retinoic acid-metabolizing enzyme expressed in the hindbrain, inner ear, first branchial arch and tooth buds during murine development. Gene Expr Patterns 3: 449-454.

ten Berge D, Brouwer A, Korving J, Martin JF, Meijlink F. 1998. Prx1 and Prx2 in skeletogenesis: Roles in the craniofacial region, inner ear and limbs. Development 125: 3831-3842.

Torban E, Patenaude AM, Leclerc S, Rakowiecki S, Gauthier S, Andelfinger G, Epstein DJ, Gros P. 2008. Genetic interaction between members of the Vangl family causes neural tube defects in mice. Proc Natl Acad Sci 105: 3449-3454.

Urness LD, Paxton CN, Wang X, Schoenwolf GC, Mansour SL. 2010. FGF signaling regulates otic placode induction and refinement by controlling both ectodermal target genes and hindbrain Wnt8a. Dev Biol 340: 595-604.

Vervoort R, Ceulemans H, Van Aerschot L, D’Hooge R, David G. 2010. Genetic modification of the inner ear lateral semicircular canal phenotype of the Bmp4 haplo-insufficient mouse. Biochem Biophys Res Commun 394: 780-785.

Wang W, Van De Water T, Lufkin T. 1998. Inner ear and maternal reproductive defects in mice lacking the Hmx3 homeobox gene. Development 125: 621-634.
Wang W, Grimmer JF, Van De Water TR, Lufkin T. 2004. Hmx2 and Hmx3 homeobox genes direct development of the murine inner ear and hypothalamus and can be functionally replaced by Drosophila Hmx. Dev Cell 7: 439-453.

Wang Y, Guo N, Nathans J. 2006. The role of Frizzled 3 and Frizzled6 in neural tube closure and in the planar polarity of inner-ear sensory hair cells. J Neurosci 26: 2147-2156.

Weston MD, Pierce ML, Jensen-Smith HC, Fritzsch B, Rocha-Sanchez S, Beisel KW, Soukup GA. 2011. MicroRNA-183 family expression in hair cell development and requirement of microRNAs for hair cell maintenance and survival. Dev Dyn 240: 808-819.

Woods C, Montcouquiol M, Kelley MW. 2004. Math1 regulates development of the sensory epithelium in the mammalian cochlea. Nat Neurosci 7: $1310-1318$.

Wright TJ, Mansour SL. 2003. Fgf3 and Fgf10 are required for mouse otic placode induction. Development 130: 3379-3390.

Wright TJ, Ladher R, McWhirter J, Murre C, Schoenwolf GC, Mansour SL. 2004. Mouse FGF15 is the ortholog of human and chick FGF19, but is not uniquely required for otic induction. Dev Biol 269: $264-275$.

Wu DK, Nunes FD, Choo D. 1998. Axial specification for sensory organs versus non-sensory structures of the chicken inner ear. Development 125: $11-20$.

Xu PX, Adams J, Peters H, Brown MC, Heaney S, Maas R. 1999. Eya1deficient mice lack ears and kidneys and show abnormal apoptosis of organ primordia. Nat Genet 23: 113-117.

Yamamoto S, Nishimura O, Misaki K, Nishita M, Minami Y, Yonemura S, Tarui H, Sasaki H. 2008. Cthrcl selectively activates the planar cell polarity pathway of Wnt signaling by stabilizing the Wnt-receptor complex. Dev Cell 15: 23-36.

Yamamoto N, Chang W, Kelley MW. 2011. Rbpj regulates development of prosensory cells in the mammalian inner ear. Dev Biol 353: 367-379.

Zhang N, Martin GV, Kelley MW, Gridley T. 2000. A mutation in the Lunatic fringe gene suppresses the effects of a Jagged 2 mutation on inner hair cell development in the cochlea. Curr Biol 10: 659-662.

Zheng W, Huang L, Wei ZB, Silvius D, Tang B, Xu PX. 2003. The role of Sixl in mammalian auditory system development. Development 130: 3989-4000.

Zine A, Aubert A, Qiu J, Therianos S, Guillemot F, Kageyama R, de Ribaupierre F. 2001. Hes1 and Hes5 activities are required for the normal development of the hair cells in the mammalian inner ear. $J$ Neurosci 21: 4712-4720.

Zou D, Erickson C, Kim EH, Jin D, Fritzsch B, Xu PX. 2008. Eyal gene dosage critically affects the development of sensory epithelia in the mammalian inner ear. Hum Mol Genet 17: 3340-3356. 


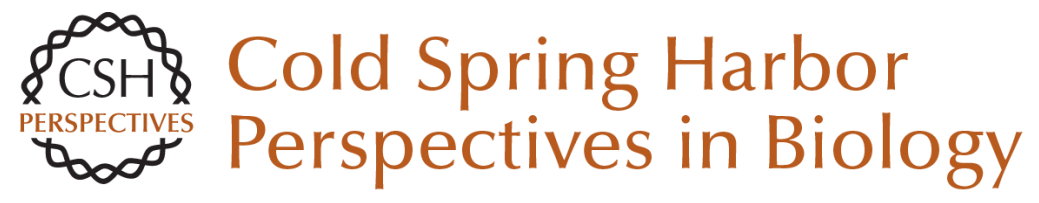

\section{Molecular Mechanisms of Inner Ear Development}

Doris K. Wu and Matthew W. Kelley

Cold Spring Harb Perspect Biol 2012; doi: 10.1101/cshperspect.a008409

Subject Collection Mammalian Development

The Dynamics of Morphogenesis in the Early Mouse Embryo

Jaime A. Rivera-Pérez and Anna-Katerina Hadjantonakis

microRNAs as Developmental Regulators Kathryn N. Ivey and Deepak Srivastava

Development of the Endochondral Skeleton Fanxin Long and David M. Ornitz

Adipogenesis Kelesha Sarjeant and Jacqueline M. Stephens

Molecular Mechanisms of Inner Ear Development Doris K. Wu and Matthew W. Kelley

Polarity in Mammalian Epithelial Morphogenesis Julie Roignot, Xiao Peng and Keith Mostov

Eye Development and Retinogenesis Whitney Heavner and Larysa Pevny

Primordial Germ Cells in Mice Mitinori Saitou and Masashi Yamaji
Cell Division Modes and Cleavage Planes of Neural Progenitors during Mammalian Cortical Development

Fumio Matsuzaki and Atsunori Shitamukai

Blood and Lymphatic Vessel Formation Victoria L. Bautch and Kathleen M. Caron

Transcriptional Networks in Liver and Intestinal

Development Karyn L. Sheaffer and Klaus H. Kaestner

Pluripotency in the Embryo and in Culture Jennifer Nichols and Austin Smith

Signaling and Transcriptional Networks in Heart Development and Regeneration Benoit G. Bruneau

Signals and Switches in Mammalian Neural Crest Cell Differentiation Shachi Bhatt, Raul Diaz and Paul A. Trainor

Hematopoiesis Michael A. Rieger and Timm Schroeder

Intercellular Interactions, Position, and Polarity in Establishing Blastocyst Cell Lineages and

Embryonic Axes

Robert O. Stephenson, Janet Rossant and Patrick P.L. Tam

For additional articles in this collection, see http://cshperspectives.cshlp.org/cgi/collection/

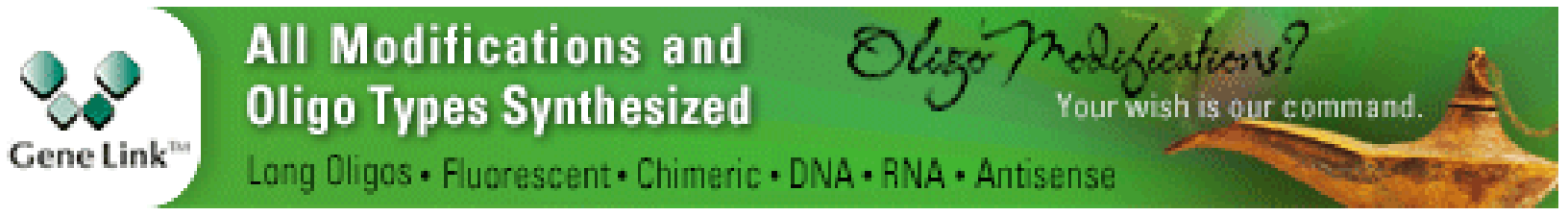

Copyright (C 2012 Cold Spring Harbor Laboratory Press; all rights reserved 